NBER WORKING PAPER SERIES

\title{
STORIES OF THE TWENTIETH CENTURY FOR THE TWENTY-FIRST
}

\author{
Pierre-Olivier Gourinchas \\ Maurice Obstfeld \\ Working Paper 17252 \\ http://www.nber.org/papers/w17252
}

\author{
NATIONAL BUREAU OF ECONOMIC RESEARCH \\ 1050 Massachusetts Avenue \\ Cambridge, MA 02138 \\ July 2011
}

Prepared for the American Economic Journal: Macroeconomics session on "Financial Crises and Macroeconomics" at the American Economic Association annual meeting, Denver, CO, January 8, 2011. We thank Galina Hale, Philip Lane, Alan Taylor and seminar participants at the European Central Bank and Columbia University for comments and data. We benefited also from the comments of the editors and three anonymous referees. Johannes Wieland, Vladimir Asriyan, and Victoria Vanasco provided dedicated research assistance. Financial support was provided by the International Growth Centre at the London School of Economics (project numbers RA-2009-11-002 and 004) and the Coleman Fung Risk Research Center at UC Berkeley. All errors are our sole responsibility. The views expressed herein are those of the authors and do not necessarily reflect the views of the National Bureau of Economic Research.

NBER working papers are circulated for discussion and comment purposes. They have not been peerreviewed or been subject to the review by the NBER Board of Directors that accompanies official NBER publications.

(C) 2011 by Pierre-Olivier Gourinchas and Maurice Obstfeld. All rights reserved. Short sections of text, not to exceed two paragraphs, may be quoted without explicit permission provided that full credit, including $($ ) notice, is given to the source. 
Stories of the Twentieth Century for the Twenty-First

Pierre-Olivier Gourinchas and Maurice Obstfeld

NBER Working Paper No. 17252

July 2011

JEL No. E32,E51,F32,F34,G15,G21

\begin{abstract}
A key precursor of twentieth-century financial crises in emerging and advanced economies alike was the rapid buildup of leverage. Those emerging economies that avoided leverage booms during the 2000s also were most likely to avoid the worst effects of the twenty-first century's first global crisis. A discrete-choice panel analysis using 1973-2010 data suggests that domestic credit expansion and real currency appreciation have been the most robust and significant predictors of financial crises, regardless of whether a country is emerging or advanced. For emerging economies, however, higher foreign exchange reserves predict a sharply reduced probability of a subsequent crisis.
\end{abstract}

Pierre-Olivier Gourinchas

Department of Economics

University of California, Berkeley

508-1 Evans Hall \#3880

Berkeley, CA 94720-3880

and CEPR

and also NBER

pog@econ.berkeley.edu

Maurice Obstfeld

Department of Economics

University of California, Berkeley

508-1 Evans Hall \#3880

Berkeley, CA 94720-3880

and CEPR

and also NBER

obstfeld@econ.berkeley.edu 
In September 1976, Britain's Labour government announced that it would seek a rescue loan from the International Monetary Fund. Italy, Portugal, and Spain also had stand-by arrangements with the IMF around that time, and even the United States, facing a weakening dollar, drew down its reserves at the IMF and exchanged Special Drawing Rights for foreign currencies. ${ }^{1}$ But after Portugal's subsequent approach to the IMF in 1983, a quarter century would pass before another high-income country sought the institution's support - a period during which the Fund lent exclusively to crisis-stricken countries in the developing world. Iceland's approach to the Fund in the autumn of 2008 was, however, soon followed by sovereign debt crises in Greece, Ireland, and Portugal virulent enough to force them, too, to seek official external support. At the time of writing (July 2011), the governments of other high-income countries such as Spain and Italy face credible threats of losing access to credit. Of course, these startling recent developments arose in part as collateral damage from the much broader global financial crisis that began in 2007 in the financial markets of the United States.

The financial and economic collapse in advanced countries caught most academic, business, and policy economists off guard. After the mid-1970s, an unstated consensus developed that financial crises were mainly emerging-market affairs. True, advanced countries such as Finland, Norway, Sweden, and Japan experienced systemic banking crises in the 1980s and 1990s. Around the same time, European countries also went through currency devaluation crises, in some cases related to banking crises. While painful, these crises were less frequent and generally less devastating than widespread cataclysms such as the 1980s developingcountry debt crisis or the 1997-98 Asian and Russian crises. Only countries in the lower income groups, it was believed, would ever need any more to seek IMF support because of a

\footnotetext{
${ }^{1}$ See Boughton (2001, p. 138).
} 
sudden stop in external finance. Sovereign default by an advanced country was unthinkable. Nothing of the sort had happened since the 1930s, when many developing countries likewise defaulted, and the early post-World War II period (Díaz-Alejandro (1983)).

Buttressing the consensus view of emerging markets as much more vulnerable to financial crisis was a large catalog of mutually reinforcing structural weaknesses that researchers identified over the years. These range from limited financial development, to faulty governance structures, to over-regulated markets, to extensive dollarization of domestic and external liabilities, to "fear of floating" the exchange rate. The mature advanced countries, it was held, were much more robust in all of these areas, and therefore were in a position to derive big net benefits from liberalized and open financial markets. But after the Asian crisis (if not before), most economists accepted the need for emerging markets to tread cautiously.

In the light of this narrative, and in the light of late twentieth-century crisis experience, the global crisis of 2007-2009 therefore produced another surprise. While some emerging countries - notably several in the former Soviet bloc - suffered greatly in the crisis, others proved remarkably resilient, often experiencing smaller output declines and faster recoveries than those in the advanced countries. Unlike in past global crises, emerging economies as a group experienced an output decline similar to that of the advanced economies, rather than greater; in general, their outputs fell from pre-crisis levels that were higher relative to trends; and their outputs returned to trend more quickly than did the outputs of the advanced economies.

Figure 1, which shows detrended real GDP growth rates for the advanced countries and the six groups of emerging market economies (EMEs), illustrates these patterns. ${ }^{2}$ The

\footnotetext{
${ }^{2}$ Data come from the IMF's April 2011 World Economic Outlook (WEO); growth rates for 2011 are IMF forecasts. For each country grouping, the growth rate of GDP is a weighted average of constant-price GDP growth rates for individual countries, the country weights being shares of GDP (measured at purchasing power parity) in group GDP (also measured at PPP). For the purpose of Figure 1 we define a group's trend
} 
Commonwealth of Independent States and Central and Eastern Europe suffered the harshest growth declines, with the former losing 11.0 percent in 2009 and the latter 7.7 percent, relative to trend. (We will discuss some reasons for these steep losses below.) Outside of these regions, the advanced countries - primarily the United States, the European Union, and Japan - suffered most, with detrended growth rates of -2.3 percent in $2008,-5.9$ percent in 2009, and 0.2 percent in 2010. The figure also shows, however, that the Asia, Middle EastNorth Africa, and Sub-Saharan Africa groups had relatively mild slowdowns in $2009(-1.0$, -2.3 and -1.3 percent respectively). While EMEs in Latin America suffered a 2009 growth loss not too far below that of the advanced countries ( -4.7 percent), this group fared much better in both 2008 and 2010 (1.5 and 3.3 percent). And there is considerable heterogeneity within the region. Brazil, for example, suffered only a minor slowdown in 2009 (-0.6 percent), while growing very strongly in both contiguous years (5.2 and 7.5 percent).

Figure 1 also shows that the decade of the 2000s until 2009 was a boom period for EMEs, with growth generally far above the long-run trend. Supporting this exceptional growth were low interest rates in the advanced economies and rising world commodity prices. Indeed, a notable absence of major emerging-market crises for several years following the 2002 crises in Argentina and Uruguay led some to speculate that the "Great Moderation" had fundamentally altered prospects for financial stability in EMEs; and the IMF, which derives its operating revenue from crisis lending, felt obliged both to downsize and to rethink its global role. Historically, EME booms often have led to crashes, and while this pattern recurred just east of the euro zone, the retrenchment elsewhere in the developing world was milder.

real growth rate as the average of annual growth rates over 1980-2011, except for the Russian federation and Central and Eastern Europe, where we use the 1994-2011 average. (In the econometric analysis later in this paper, we use a different method to detrend the level of real GDP, as is explained below.) The grouping of countries is discussed in more details in section 2.2. A number of other studies have analyzed the relative output performance of EMEs and advanced economies in the recent global crisis. For surveys, see Kose and Prasad (2010) and Didier et al. (2011). 
Following the September 2008 Lehman Brothers failure, financial flows to emerging markets certainly contracted abruptly, world export demand collapsed temporarily, and many EME currencies depreciated sharply. But most of the emerging world escaped systemic banking crises and sovereign defaults. The outcome was very different from that of the 1980s debt crisis, which also originated in a context of deep global recession.

In this paper we compare features of economic crises in advanced and developing economies. The 2007-2009 crisis, with its seemingly divergent impacts on the advanced economies and different groups of EMEs, can yield clues about the fundamental causes and consequences of crises. We can hope to learn by comparing the characteristics of crises in different epochs, by comparing across economies at distinct stages of development, and by distinguishing among different types of crisis and different mechanisms of international transmission or contagion.

An important conclusion is that crises in emerging and advanced economies have their origins in very similar underlying factors. Two seem especially important: a buildup of domestic and external leverage in a context of explicit or implicit government guarantees to a liberalized financial sector, and real currency appreciation. ${ }^{3}$ Thus, the recent advanced country experience, like that of some euro zone economies, has many hallmarks of earlier "emerging market" crises in Latin America and Asia. An economy's structural features determine the likelihood that one or more causal factors triggers a crisis, as well as the severity of its effects; but these are differences of degree, not of kind. At least over the first decade of the twenty-first century, structural evolution appears to have raised the crisis sensitivity of advanced economies relative to that of many emerging economies, making the

\footnotetext{
${ }^{3}$ The role of credit booms is familiar from studies such as Díaz-Alejandro (1985), McKinnon and Pill (1996), Sachs et al. (1996), Kaminsky and Reinhart (1999), Corsetti et al. (1999), Dooley (2000), Gourinchas et al. (2001), Tornell (2001), Glick and Hutchison (2001), Hernandez and Landerretche (2002), Mendoza and Terrones (2008), Schularick and Taylor (2009), and Reinhart and Reinhart (2011). Among macroeconomists, however, real appreciation as a prologue to crises received much more attention than credit-market factors until the latter 1990s. Dornbusch et al. (1995), among a host of others, stress the role of real appreciations.
} 
latest global crisis work out quite differently so far from twentieth-century crises for many EMEs. We add the qualifier "so far" because, as we shall see below, current EME financial inflows and credit expansion, fueled by both the EMEs' relative economic strength and continuing expansive monetary policies in richer countries, may signal financial problems down the road.

The plan of the paper is as follows. In section I we distinguish among alternative varieties of financial crisis and discuss the structural weaknesses of EMEs that have tended over the past to make them especially susceptible to crises. We document the frequency of different types of crisis in advanced economies and EMEs. Section II analyzes key economic data from advanced economies and EMEs around different types of crisis. Our goal is to compare salient features of similar crises in advanced and emerging economies, as well as differences between past crises (from 1973 to 2006) and the 2007-2009 crisis. We employ two complementary methodologies to explore the data: event studies of how key economic variables behave around different categories of crisis, as well as logit analyses of crisis probabilities. In the light of that evidence and a developing body of empirical research, Section III advances hypotheses about why less-developed countries on the whole did not fare worse than advanced economies in the current crisis, and why the impact differed so markedly across different emerging regions. Section IV concludes.

\section{Crisis Types and Emerging Market Vulnerabilities}

Economists have studied many types of financial crisis, but our analysis is restricted to three that tend to be closely interrelated in practice: currency crises (in which a managed exchange rate falls to speculative pressure), banking crises (including instability in the shadow banking 
system), government default crises (involving default or market fears of explicit default on internal or external public debt). Banking crises can involve a limited range of institutions, so that their collateral impact on the core of the financial system is contained, as in the United States Savings and Loan crisis. We focus instead on systemic banking crises, which endanger the entire economy (and possibly, through various channels of contagion, foreign economies).

The links between "twin" banking and currency crises are well known. As documented by Kaminsky and Reinhart (1999), banking crises tend to begin ahead of currency crises when the two occur together, with flight from the financial system and government liquidity support for banks soon leading to flight from the currency and thus, massive depreciation. Currency depreciation fears exacerbate (and may themselves cause) banking problems as domestic-currency depositors switch into foreign exchange perhaps due to higher interest rates as authorities try (usually in vain) to defend the currency. If banks or bank borrowers have unhedged debts denominated in foreign currency, currency depreciation inflates the real value of bank liabilities or, by rendering bank borrowers insolvent, reduces bank assets.

A systemic banking crisis, especially if exacerbated by currency depreciation, can jeopardize the public finances as the government intervenes to guarantee bank liabilities, acquire impaired bank assets, or inject capital. If sufficiently expensive, these bailout measures may add a third sibling - a sovereign default crisis - to the twins. Of course, a default crisis may originate in simple fiscal profligacy rather than a private-sector financial collapse, although currency and banking problems are likely to follow. Default on public debt must be explicit if government bonds are indexed or foreign-currency denominated, but for debts in domestic currency, default may (but need not) take the form of surprise inflation. ${ }^{4}$ In this paper we

\footnotetext{
${ }^{4}$ See Reinhart and Rogoff (2009, partIII).
} 
consider only explicit default episodes.

Data from the 1970s through 2007 (covering the impact as well as the frequency of events) suggest that emerging markets were particularly susceptible to currency, banking, and sovereign default crises prior to the recent global crisis. A large empirical literature seeks to document the timing of financial crises, and while alternative criteria can yield somewhat different conclusions (especially with regard to timing), the broad empirical regularities concerning crisis incidence are fairly uncontroversial. We draw our dating of systemic banking crises and sovereign default crises from Reinhart and Rogoff (2009), Caprio et al. (2003), Laeven and Valencia (2010), Cantor and Packer (1995), Chambers (2011), Moody's (2009), and Sturzenegger and Zettelmeyer (2007). To date EME currency crises we use the criterion of Frankel and Rose (1996) - a 25 percent or greater nominal currency depreciation over a year that is also a 10 percentage point increase in the annual rate of depreciation. For advanced economies we use the chronology of Bordo et al. (2001), which extends through 1997. After 1997 there were no true currency crises in advanced countries until 2008, notwithstanding the ersatz crises some authors have identified using mechanical criteria.

Table 1 shows that in the past, crises in general have been much more prevalent in EMEs. All of the 74 (external and internal) sovereign default episodes occurred in EMEs, although several peripheral euro zone are now on the brink of joining the list. Fifty seven of the 62 pre-2007 systemic banking crises took place in EMEs, and EMEs had about twice as many currency crises, often-times not in conjunction with banking crises. ${ }^{5}$

Several characteristics of EMEs differentiate them from advanced economies and made them especially crisis-prone in the past. Countries naturally differ among each other, making

\footnotetext{
${ }^{5}$ The five systemic advanced-country banking crises occurred in Spain, Japan, Norway, Finland, and Sweden. Notice that while the number of currency crises per country is not especially low for advanced economies, our criterion for an advanced-country currency crisis, described earlier, is more lenient than for EMEs.
} 
generalizations imperfect, but a majority of the features we describe below have applied to most EMEs. In turn, these distinctive features mostly stem from a deeper source: a level of institutional quality generally lower than that in advanced economies.

Economists believe that the efficacy of a country's governance institutions is central to understanding its income per capita, as well as other key features of its economic performance. While quantitative measures of institutional quality are necessarily crude, they uniformly point to lower average quality in the emerging world compared with mature economies. ${ }^{6}$ In turn, these shortcomings in governance are closely linked to most of the items on economists' standard list of emerging-market weaknesses, which emerged out of twentieth-century experience:

- Political and economic instability. Political instability breeds economic instability, as illustrated by the relatively more variable EME growth rates through 2007 shown in Figure 1 (see, for example, Acemoglu et al. (2003)). Macro policies tend to be procyclical (Kaminsky et al. (2005)) due to conflicts over windfalls in good times and the absence of predictable and widely accepted mechanisms to allocate losses in bad. Inflation is a favored method of resolving distributional disputes that the political process cannot settle (Rajan and Tokatlidis (2005)). Difficulty in levying and collecting taxes worsens the fiscal position overall, contributing both to procyclicality and the reliance on inflation. Volatility may be heightened by undiversified export mixes, for example, reliance on a few main commodity exports.

\footnotetext{
${ }^{6}$ Naturally there are exceptions. For example, Chile in 2010 surpassed the United States on Transparency International's inverse index of corruption (and in the same year entered the OECD). Nonetheless, there is a strong positive correlation between the Transparency International index and real per capita GDP. The World Bank's Worldwide Governance Indicators project measures institutional quality along six dimensions: voice and accountability, political stability and absence of violence, government effectiveness, regulatory quality, rule of law, and control of corruption. All of these measures correlate positively with per capita income. Of course, there is a two-way causality, since institutional imperfections impede wealth accumulation but likewise are more likely when resources for investment in institutional quality are low.
} 
- Undeveloped and unstable financial markets. Unreliable contract enforcement dictates a reliance on relatively simple, information-insensitive, noncontingent financial contracts. Imperfect protection of equity investors fosters ownership concentration and limits gains from risk sharing, domestic and international (Stulz (2005)). At the same time, government restrictions may discourage competition and innovation in financial markets, allowing connected lending and other forms of cronyism to flourish. A lack of financial depth limits the economy's ability to absorb economic shocks. While bureaucratic restrictions abound, effective enforcement of prudential standards often lags because of opaque accounting practices, corruption, and a lack of expertise. Weak political institutions limit the checks and balances needed to minimize abuses. As Díaz-Alejandro (1985, p. 20) observes in his classic analysis of Latin American financial instability, "[D]emocracy, whatever its more fundamental virtues, is an important technical input for a healthy domestic financial system." An expectation that government will bail out failing financial institutions, validated by experience in Latin America, Asia, and elsewhere, creates moral hazard. This spells trouble when financial transactions are liberalized (externally or domestically) without adequate prior safeguards (see, for example, Demirgüç-Kunt and Detragiache (2000); Honohan and Klingebiel (2003)).

- Dollarization, original sin, and currency mismatches. Frequent recourse to inflationary finance in the past has created a tendency for financial contracts to be denominated in a stable foreign currency, such as the U.S. dollar or euro (Eichengreen et al. (2007); Goldstein and Turner (2004); Rajan and Tokatlidis (2005)). This tendency applies both to internal contracts and external loan agreements; in the latter context, the inability to borrow from foreigners in domestic currency is conventionally referred to as "original 
sin." Domestic liability dollarization has an important advantage for creditors over alternative form of real principal protection, such as price-level indexation: it does not depend on government discretion with respect to inflation measurement or the timing of inflation adjustment. Unfortunately, dollarization of liabilities is likely to entail a short position in dollars for the home banking system, either explicitly or implicitly, because even bank loans to domestic customers that are denominated in dollars on paper are likely to go bust when a sudden currency depreciation raises the real value of the loan. For a sample of about a hundred developing economies, Nicolò et al. (2005) document the links between macro instability and dollarization of bank deposits and between dollarization and financial instability. At the national level, original sin implies that currency depreciation will raise the real value of external debt. Through these mechanisms, as we have noted, sharp currency depreciations can lead to financial crises.

- Fear of floating. Even where emerging markets have not literally pegged their currencies' foreign exchange values, they have shown less willingness to tolerate sharp nominal exchange rate movements than the advanced countries (Calvo and Reinhart (2002); Hausmann et al. (2001)). Fear of sharp appreciation and its negative effect on exports is evidenced in the recent controversy over "currency wars." Particularly when an EME is financially open and faces financial inflows, as has been the case for many in recent years, intervention to resist currency appreciation, coupled with incomplete sterilization of reserve inflows, may undermine domestic inflation targets, bid up asset prices, and push domestic credit expansion to dangerous levels. EMEs also have feared sharp currency depreciation, as depreciation can cause debt deflation (in the presence of currency mismatch) and a jump in inflation. Indeed, once the domestic currency begins to depreciate, dollar debtors may scramble for that currency in order to un- 
wind short positions, leading to further depreciation and heightened financial distress. Some argue that the government's reluctance to allow sharp exchange rate movements in the past has itself contributed to currency mismatch - there may be an expectation that official intervention to support the exchange rate will allow dollar debtors to close out their short positions at public expense (Mishkin (1998); Burnside et al. (2001); Schneider and Tornell (2004)). ${ }^{7}$

- Sudden stops and debt intolerance. EMEs have been vulnerable to sudden stops in foreign lending, which may require not only a sharp reduction in the current account deficit also but abrupt demands for repayment of short-term external debt (Calvo and Reinhart (2000); Milesi-Ferretti and Razin (2000); Edwards (2004); Forbes and Warnock (2011)). Unless the country can draw on official foreign exchange reserves or relatively liquid gross assets held abroad by the private sector, such events typically will be associated with abrupt currency depreciation and the associated financial repercussions. Financial fragility and the government's weakness in generating resources for debt repayment are conducive to volatility in capital flows. At the same time, credit rationing may occur at external debt levels far below those that advanced countries seem able to sustain - a phenomenon that has been labeled "debt intolerance" by Reinhart et al. (2003).

- Over regulation of nonfinancial markets. Heavy regulation in product and labor markets reduces flexibility in resource reallocation following economic shocks. In particular, structural rigidities help explain the fear of floating, because unexpected exchange rate movements have magnified effects on sectoral imbalances and intersectoral adjustment

\footnotetext{
${ }^{7}$ For the argument that fixed exchange rates are not a primary cause of currency mismatch, see Honig (2009).
} 
costs. Thickets of administrative barriers to economic activity, such as licensing requirements, promote corruption as well as inefficiency.

In view of this array of structural defects, it is all the more impressive that emerging markets did not suffer even more in the recent global crisis. As we discuss below, many observers believe that some EMEs have made progress repairing or at least compensating for these weaknesses. On the other hand, recent events make mature economies appear suddenly vulnerable to some aspects of these "emerging-market" weaknesses. Advanced countries still score generally well in terms of political and economic stability, ability to use the exchange rate as a shock absorber, and flexibility in nonfinancial markets. ${ }^{8}$ But their financial markets have caused problems. ${ }^{9}$

Consider financial development. This area of relative advanced country "strength" arguably exacerbated the effects of the crisis in the rich economies. Table 2 shows ratios of total commercial bank assets relative to GDP in 2003 and 2007 for a range of countries. (Total banking system assets are greater.) As is apparent, emerging markets, in general, have smaller banking systems than the mature economies. ${ }^{10}$ Furthermore, there is a remarkable divergence in the growth of banking assets between 2003 and 2007. EU bank assets increased by a staggering 97.6 percent of EU GDP, whereas EME bank assets grew by far less - emerging Europe showing the biggest increase. The growth of United States bank-

\footnotetext{
${ }^{8}$ Of course there are exceptions, for example, the structural labor-market rigidities leading to high unemployment in some advanced countries.

${ }^{9}$ Arguably the widespread resistance to recognizing advanced-country financial weaknesses until now represents past escapes from disaster, as well as an important element of denial. Reviewing the U.S. financial market turmoil of late 1998, for example, Lamfalussy (2000) (p. 140f) wrote, "If such developments can take place in the model market of the world, what is the practical value of recommending that emerging markets copy this model?"

${ }^{10}$ United States banking assets appear moderate in relation to GDP due to the importance of the shadow banking sector, which is much less developed in other high-income countries. The Asia aggregate in Table 2 includes the (now) high-income "newly industrialized Asia" group consisting of Hong Kong, Korea, Singapore, and Taiwan. These countries generally have banking systems more extensive than those in poorer emerging Asian countries.
} 
ing assets that the table reports seems moderate, but omits a substantial contribution from off-balance-sheet vehicles.

In EU and other rich countries, lax prudential oversight in the face of the rapid financialmarket expansion of the 2000s has increased the level of financial risk. In marked contrast to the pre-2007 experience summarized in Table 1, ten advanced countries had systemic banking crises in 2007-2009 and a further six had milder (but still costly) "borderline" systemic crises (according to the classifications of Laeven and Valencia (2010)). Only two EMEs (Latvia and Ukraine) had systemic banking crises in those years, while four more (Hungary, Kazakhstan, Russia, and Slovenia) had borderline systemic crises. ${ }^{11}$

Experience in emerging and advanced economies alike shows that no government will allow a domestic financial system collapse if it can marshal the resources to prevent it. Apparently, moral hazard does not discriminate across income levels. The sizes of some advanced country bank balance sheets, however, make obvious the dangers to the rich countries' public finances of broad banking system guarantees Other things equal, fiscal support of the banking system in times of stress may be more feasible for the government budget of an EME, whereas for some advanced economies even a year's GDP might not suffice to handle a severe systemic crisis. While all the industrial countries currently face aggravated fiscal adjustment challenges as a result of past interventions to support their financial sectors, countries with banking-system balance sheets that are multiples of GDP are especially at risk for the future. Sovereign defaults (which themselves are likely to have adverse political consequences) are no longer unthinkable for rich countries. The events leading to Ireland's recent sovereign debt problems are a case in point. ${ }^{12}$

\footnotetext{
${ }^{11}$ In 2008, Mongolia, which we consider to be a non-emerging developing country, also had a systemic banking crisis according to Laeven and Valencia (2010). Their list does not include some more limited events, such as Nigeria's 2009 banking stress.

${ }^{12}$ Even leaving aside their partial coverage of the banking system, the numbers in Table 2 may not ac-
} 
High levels of intermediation in mature financial markets have likewise given rise to substantial currency mismatches. Extensive European bank investments in U.S. subprimerelated securities, financed by short-term wholesale dollar borrowing, led to dollar shortages in 2007-2009 when dollar funding markets froze. The dollar appreciated sharply. Federal Reserve swap lines, first extended in December 2007 and renewed several times since then, were particularly helpful for European banks seeking to avoid distress sales of dollar assets (although the swaps were made available to a small group of EMEs as well). The European banks' plight demonstrates how, even in an advanced country crisis, maturity or other mismatches between foreign currency assets and liabilities can rapidly morph into currency mismatch.

Finally, advanced economies also saw sudden stops in the aftermath of the Lehman collapse. United States balance of payments data, for example, show that from 2008:IV through 2009:II, foreign lenders ceased lending to the U.S. and indeed, liquidated nearly $\$ 165$ billion in U.S. assets. Unlike emerging markets, however, U.S. residents hold a stock of gross foreign assets that is higher than GDP. As a result, they were able to meet foreign repayment demands, at the same time financing a continuing current account deficit, by selling off their own assets located abroad. Since the sell-off included claims on emerging markets, it is all the more striking that a majority of EMEs did not suffer financial collapse in the crisis.

We summarize as follows. Crises of several types have been frequent since 1970 (and of course were common in earlier epochs). Because of several structural weaknesses in the polities and economies of emerging markets, crises have been much more common there.

curately represent the potential claim on public sector resources arising from bank rescues. Some of the assets measured in these numbers are held by banks with primarily foreign operations, and little connection on either the asset or liability side to the domestic economy. On the other hand, a government could face pressures to rescue a domestically-owned bank with primarily foreign operations. 
However, some features of advanced economies that sometimes are viewed as strengths notably financial depth - pose threats as well, given limited prudential oversight, bailout expectations, and other market incentives for socially excessive risk taking. At the same time, some EMEs have labored over the early twenty-first century to reduce their vulnerabilities, and these efforts may have borne fruit in the recent crisis. We next turn to the data to compare EME and advanced country performance.

\section{Some Empirics of Crises: Emerging and Advanced Economies, Then and Now}

Two types of comparison, across country types and across time, interest us. These are motivated by two questions: How have crises differed, in their precursors and aftermaths, between emerging and advanced economies? And in both sets of countries, how does the crisis of 2007-2009 differ from earlier crises? Ultimately, we hope the data will help us to understand the different experiences of advanced and emerging economies, as well as of different regional groupings of emerging economies, in the recent crisis. The structural features of EMEs listed in the last section change slowly over time and thus are not easily amenable to time series analysis. However, our comparisons across country groups and time periods are intended to capture broad structural differences.

In the spirit of Eichengreen et al. (1995), Kaminsky and Reinhart (1999), and several subsequent authors, we examine the behavior of key economic variables around crisis episodes. We focus on variables which, according to theory and earlier empirical research, are likely to play a causal role in determining the probability of a crisis, are likely to be affected by a crisis, or both. While Kaminsky and Reinhart (1999) average their data over cross sections 
consisting of country-crisis pairs, relying on different cross sections for information on different crisis types, we take an alternative approach. Instead, we estimate directly how an economic variable's conditional expectation depends on temporal distance from each of three types of crisis - default (internal or external), banking, and currency - given the proximity of other crisis types.

More specifically, we examine the behavior of output, domestic credit, the current account balance, external leverage, the real interest rate, the real exchange rate, international reserves, and fiscal variables. The relevance of most of these variables will be obvious. For example, a rapid buildup of domestic credit can undermine a currency peg as the central bank loses foreign exchange reserves, while simultaneously setting the stage for a private banking collapse and a setback to government solvency. Likewise, significant real currency appreciation has often preceded financial crises.

We then tackle the obvious question: to what extent are the same macroeconomic and financial variables useful in predicting the onset of crises? Do emerging markets collapse every time credit growth is high? Do the currencies of advanced economies' crash systematically in the aftermath of a significant real appreciation? We answer this question by using discretechoice models to estimate the probability of a given type of crisis as a function of the same set of variables.

\subsection{Methodology}

Consider a variable of interest $y_{i t}$, where subscript $i$ refers to the country and subscript $t$ to the period. Our approach is to estimate the conditional expectation of $y_{i t}$ as a function of the temporal distance from various types of crisis, relative to a common "tranquil times"

baseline. As discussed in the previous section, our benchmark estimation considers four 
possible crisis types: domestic and external default, systemic banking crisis, currency crisis, and the global financial crisis of $2008 .^{13}$

We postulate the following fixed-effects panel specification:

$$
y_{i t}=\alpha_{i}+\beta_{d s} \delta_{d s}+\beta_{b s} \delta_{b s}+\beta_{c s} \delta_{c s}+\beta_{g s} \delta_{g s}+\epsilon_{i t}
$$

In equation (1), $\delta_{j s}$ denotes a dummy variable equal to 1 when country $i$ is $s$ periods away from a crisis of type $j$ in period $t$. The index $j$ denotes, respectively, default $(d)$, systemic banking crisis $(b)$, currency crisis $(c)$ and the 2008 global financial crisis $(g)$. We set the event window around crisis episodes to 11 years (five years before, five years after) so as to allow the relatively slow adjustment that typically follows a financial crisis (Reinhart and Rogoff (2009); Reinhart and Reinhart (2011)). The regression also allows for country fixed effects $\alpha_{i}$. Finally, the error term $\epsilon_{i t}$ captures all the remaining variation in the realization of the variable of interest.

A number of observations about our empirical specification are relevant at this stage. First, the coefficients $\beta_{j s}$ are our primary parameters of interest. They measure the conditional effect of a crisis of type $j$ on variable $y$ over the event window $-5 \leq s \leq 5$ relative to "tranquil times." 14 Since the "tranquil time" baseline is common to all types of crisis, we are measuring the impact of different crises relative to a common reference level. This is important because it will allows us to measure directly and compare how different macro and financial variables evolve over different crisis episodes. In particular, comparison of $\beta_{g s}$

\footnotetext{
${ }^{13}$ As noted earlier, we date domestic and external defaults following Reinhart and Rogoff (2009); systemic banking crises according to Laeven and Valencia (2010); EME currency crises following the criteria set out in Frankel and Rose (1996); and advanced countries currency crisis according to the Bordo et al. (2001) classification. We assume that all countries were potentially affected by the global financial crisis, which we view as starting in 2008 , when it first became truly systemic.

${ }^{14}$ Tranquil times are implicitly defined as the country-year observations that do not fall into any crisis-event window.
} 
and $\beta_{j s}$ for $j \neq g$, provides us with a direct assessment of the similarities between the recent global financial crisis and earlier crises of various kinds.

Second, because we consider that all countries are "treated" by the recent global financial crisis, the coefficients $\beta_{g s}$ have the interpretation of year-effects for the period 2003-2010. Hence, $\beta_{g s}$ measures the deviation of the cross section average in the corresponding years from the "tranquil time" baseline, itself estimated over the period 1973-2002 and purged of crisis episodes. Unlike simple deviations from trend (which potentially include earlier crisis episodes), we therefore construct a potentially cleaner estimate of the build-up and subsequent impact of the global financial crisis. ${ }^{15}$

Third, our specification easily handles repeat or multiple crises, of the same type or of different types, with one important caveat. For instance, the estimated conditional mean for a country one year away from a currency crisis and one year after a banking crisis is simply $\hat{\beta}_{-1 c}+\hat{\beta}_{1 b}$. There is no need to decide whether recurrent episodes are really part of a single larger crisis, or to extend event-windows to encompass different crisis manifestations. The caveat, as the formula above illustrates clearly, is that our specification does not allow for interaction effects. In other words, it does not allow for the amplification and feedback effects between different types of crisis or repeated crises. The effect of a twin banking and currency crisis, in the simplified setting we assume, is simply the sum of the effect of an isolated banking crisis, $\hat{\beta}_{b}$, and an isolated currency crisis, $\hat{\beta}_{c}$. This simplification has potentially important drawbacks, as our earlier discussion of potential two-way feedback loops between currency and banking crises shows. ${ }^{16}$ Potential linkages also exist also between banking crisis and domestic or sovereign defaults episodes.

\footnotetext{
${ }^{15}$ Obviously, our approach still requires that we control for non-stationarities in the data; otherwise the "tranquil time" benchmark would not be appropriate.

${ }^{16}$ There are numerous discussions in the literature, including Kaminsky and Reinhart (1999), Obstfeld (2004), Rajan and Tokatlidis (2005), and references therein.
} 
These concerns can be addressed by estimating a variation of equation (1) that includes interaction effects:

$$
y_{i t}=\alpha_{i}+\sum_{j} \beta_{j s} \delta_{j s}+\sum_{j k} \beta_{j k s} \delta_{j k s}+\epsilon_{i t} .
$$

In equation (2) $\delta_{j k s}$ is a dummy equal to one when country $i$ is $s$ periods away from joint crisis of type $j$ and $k$ in period $t .{ }^{17}$ The corresponding coefficients $\beta_{j k s}$ have a particularly simple interpretation in the case where $\delta_{j k}=\delta_{j} \delta_{k}$, that is, when $\delta_{j k}$ is simply the interaction of the crisis dummies of type $j$ and $k$. In that case, $\beta_{j k s}$ represents the difference-in-difference estimator of the effect of a joint crisis, over and above the effect of an isolated crisis. In theory, this specification allows us to test directly for interaction effects of the kind described in the literature. ${ }^{18}$ In practice, including all types of crisis and all possible interactions quickly makes all coefficients statistically insignificant. Given the focus in the literature on twin banking and currency crises, we implemented a version of equation (2) involving banking and currency crisis episodes only (along with their interaction). ${ }^{19}$ Nevertheless, we found that estimates of the interaction terms $\beta_{c b s}$, while sometimes large in magnitude, were most often statistically insignificant. This finding suggests that, while banking and currency crises can potentially interact in major ways, the effects do not appear systematic. In what follows, we therefore omit interaction terms.

\footnotetext{
${ }^{17}$ In practice, we allow for the fact that joint crises have some dynamic features and need not necessarily happen in exactly the same year. We set $\delta_{j k 0}$ equal to 1 if a crisis of type $j$ or $k$ occurs in year $t$, a crisis of type $j$ or $k$ occurs in year $t+1$, but there is no crisis of type $j$ or $k$ in year $t-1$.

${ }^{18}$ By contrast, Kaminsky and Reinhart (1999) do not estimate the treatment effect of a joint crisis, relative to an isolated crisis. They report estimates of the effect of a joint crisis, that is, $\beta_{c}+\beta_{b}+\beta_{c b}$, and unconditional estimates of the effect of a crisis of type $j$. For example, for a currency crisis, the unconditional effect they estimate corresponds to the $\beta_{c}+\beta_{b} E\left[\delta_{b} \mid \delta_{c}=1\right]+\beta_{c b} E\left[\delta_{c b} \mid \delta_{c}=1\right]$.

${ }^{19}$ Indeed, twin banking-currency crises are quite prevalent in our sample. Of the five systemic banking crises for advanced economies, three are twin banking-currency crises - Spain (1977), Finland (1991), and Sweden (1991) - whereas the remaining two - Norway (1991) and Japan (1997) - are isolated banking crises. Of the 42 banking crises in EMEs, 36 are twinned with currency crises according to our classification.
} 
Finally, we implement equation (1) separately on advanced and emerging market economies. As the discussion of the preceding section made clear, allowing for different crisis dynamics for the two groups of countries will allow us to answer two important questions: How have the crises of EMEs and advanced economies differed in the past (that is, is $\hat{\beta}_{j s}^{\text {eme }}$ different from $\left.\hat{\beta}_{j s}^{a d v}\right)$ ? And how does the current crisis differ from earlier crises (that is, is $\hat{\beta}_{g s}^{a d v}$ or $\beta_{g s}^{e m e}$ similar to $\hat{\beta}_{j s}^{a d v}$ or $\left.\hat{\beta}_{j s}^{e m e}\right)$ ?

\subsection{What Happens Before, During and After Crises?}

We now systematically evaluate the relative behavior of various macroeconomic and financial variables around crises events by estimating equation (1). We consider 11 variables, covering various aspects of the domestic, external, real, and financial environment. ${ }^{20}$

Our sample of emerging market economies comprises all countries for which data are available that are included in either J.P.Morgan's EMBIG index, the FTSE's Group of Advanced or Secondary Emerging markets, the MSCI-Barra classification of Emerging or Frontier economies, and the Dow-Jones list of Emerging Markets Economies. These outlets determine lists of emerging market economies based on indicators of economic development and financial market infrastructure. To these countries, we add Israel, Hong Kong and Singapore, all countries that recently graduated to the group of advanced economies but properly belong to the group of emerging market economies for most of our sample period. Because our discussion stresses international financial linkages and financial vulnerabilities, we also exclude from consideration lower-income developing countries with relatively undeveloped financial sectors and relatively limited financial openness. ${ }^{21}$ Our final list contains 57 emerg-

\footnotetext{
${ }^{20}$ All data sources are described in appendix B.

${ }^{21}$ For these reasons, our group of EMEs differs from that used by the IMF's World Economic Outlook..
} 
ing market economies distributed among six regional groupings. ${ }^{22}$ In addition, we compile data for 22 advanced economies. ${ }^{23}$

We begin with a measure of real activity, the output gap, constructed as the deviation of the log of real output from a Hodrick-Prescott (HP) trend. ${ }^{24}$ The results from the estimation of equation (1) are presented in the top panel of figure 2. Because we will make repeated use of that figure, let us spend a moment describing the information it contains. The top row, labeled "EM," reports the estimates for our sample of 57 emerging market economies. The bottom row, labeled "ADV," reports the coefficients of advanced economies. Each column (labeled, respectively "Default," "Banking," "Currency," and "2008") refers to a different type of crisis, with the first three columns referring to pre-2007 crises only. Finally, in each panel the solid line reports the coefficients $\hat{\beta}_{j s}$ over the event window, together with a 95 percent confidence interval. ${ }^{25}$ The beginning of a crisis ( $s=0$ in event time) is indicated by

\footnotetext{
${ }^{22}$ The list of EMEs is as follows. Middle East and North Africa (10 countries): Egypt, Iraq, Israel, Jordan, Kuwait, Lebanon, Morocco, Oman, Tunisia, United Arab Emirates. Latin America (13 countries): Argentina, Brazil, Chile, Colombia, Dominican Republic, Ecuador, El Salvador, Jamaica, Mexico, Panama, Peru, Uruguay, Venezuela. Asia (11 countries): China, Hong Kong, India, Indonesia, Korea, Malaysia, Pakistan, Philippines, Singapore, Sri Lanka, Thailand. Sub-saharan Africa (3 countries): Côte d'Ivoire, Nigeria, South Africa. Commonwealth of Independent States (5 countries): Belarus, Georgia, Kazakhstan, Russian Federation, Ukraine. Central and Eastern European (15 countries): Bosnia, Bulgaria, Croatia, Czech Republic, Estonia, Hungary, Latvia, Lithuania, Macedonia, Poland, Romania, Serbia, Slovak Republic, Slovenia, Turkey.

${ }^{23}$ The list of advanced economies is follows: Australia, Austria, Belgium, Canada, Denmark, Finland, France, Germany, Greece, Iceland, Ireland, Italy, Japan, Netherlands, New Zealand, Norway, Portugal, Spain, Sweden, Switzerland, United Kingdom, United States.

${ }^{24}$ We set the smoothing coefficient of the HP filter at 100 . With annual data, this filters out more than $30 \%$ of cycles of periodicity higher than 16 years (64 quarters) - see King and Rebelo (1993, p. 220). Typical U.S. business cycle applications usually set the smoothing parameter at 1600 (on quarterly data) or 6.25 on annual data - see Ravn and Uhlig (2002). This filters out more than $30 \%$ of cycles of periodicity higher than 32 quarters. Because boom-crisis-bust dynamics often occur on a timescale slower than U.S. business cycles, we view our focus on lower frequencies as sensible. Our results are robust to reasonable variation in the smoothing coefficient, as long as our estimate of the output gap includes medium-run frequencies, including linear detrending at one extreme.

${ }^{25}$ That is, we graph approximately two standard deviations on each side of the estimated coefficients, unlike Kaminsky and Reinhart (1999), who graph only one standard deviation on each side. Our estimates are based on robust (White) standard errors. Similar results (but with somewhat larger standard errors) are obtained when clustering EMEs by region. Given the global propagation of trade and especially financial
} 
a vertical dashed line.

Figure 2(a) presents patterns relating to real GDP. The first three columns for EMEs show that output tends to be significantly above trend (a positive output gap) in the years preceding default and banking crises, relative to tranquil times. ${ }^{26}$ This is true for advanced countries as well (bottom row), though, given the small number of banking crises, the estimated deviations are less significant. By contrast, in the run up to a currency crisis, the output gap is negative - slightly for advanced economies but more so for EMEs. The patterns are consistent with the view that banking crises are often preceded by exuberant and unsustainable levels of economic activity, fueled by cheap credit. The contrasting morose environment that precedes currency crises often reflects in part the contractionary efforts imposed by a central bank trying to defend a currency peg under attack. Currency crises can occur precisely when economic conditions take a turn for the worse and investors lose confidence in the willingness of authorities to defend the peg, or following a period of above average domestic inflation that appreciates the currency and worsens external balances, depressing aggregate activity.

All crises are associated with a significant decline in the output gap relative to tranquil times. Output falls relatively less in advanced countries and recovers faster than for EMEs in the aftermath of a currency crisis, perhaps because of negative wealth effects in EMEs of the type highlighted in the literature on contractionary devaluation.

A quantitative comparison between advanced and EME banking crises reveals several differences. Both groups of countries experience abnormally high economic activity before a banking crisis, around 2 percent above potential for advanced countries and 4.6 percent for EMEs. But the decline in output is larger for the latter group (8.5 percent from peak shocks, however, the theoretical basis for regional clustering seems weak.

${ }^{26}$ However, output growth seems to slow before both types of crisis. 
to trough) as compared to advanced economies (5.2 percent). Levels of economic activity also remain depressed for a significant period following an advanced country banking crisis, a finding similar to those of Reinhart and Rogoff (2009) and Reinhart and Reinhart (2011). Indeed, our point estimates suggest that the recovery from banking crises is slower for advanced countries. Five years after the beginning of the systemic phase of the banking crisis (which may itself have been preceded by an extended period of financial distress), output remains significantly depressed for these countries (1.6 percent below potential). By contrast, emerging markets appear somewhat more resilient faced with banking crises, and their output recovers within five years. ${ }^{27}$ This last result may be a consequence of the higher level of development and sophistication of advanced economies' banking and financial sectors. As the example of Japan illustrates, an economy with a complex financial system may take much more than five years to recover once that system is impaired. Our findings do not contradict the view that past financial crises were on the whole relatively more costly for EMEs, because EME banking crises often coincided with currency crises, default crises, or both.

Finally, a comparison of previous crises and the recent global crisis reveals a number of facts. First, the run up to the 2008 crisis, like earlier financial crises, was characterized by above-trend economic activity. The positive output gap is especially salient for emerging countries (reaching a peak of 3.8 percent in 2008), but also for advanced economies (3.3 percent in 2007). From that point on, two findings are worth noting. First, the post-crisis absolute deviation of output from trend has been somewhat smaller in emerging than in advanced economies (2.6 percent versus 3.6 percent). This confirms the evidence presented in figure 1: on the whole, emerging markets displayed resilience compared to their performance

\footnotetext{
${ }^{27} \mathrm{~A}$ formal statistical test, however, would likely not reject the hypothesis that the post-crisis output paths for the two groups are the same.
} 
in past crises. Second, the overall slowdown in advanced economies is even larger than those experienced during earlier major banking crises. Based on the severity of the output slowdown, the recent experience of advanced economies resembles most that of earlier systemic banking crisis episodes, except on a larger and broader scale.

The bottom panel of figure 2 reports our findings for consumer price inflation. ${ }^{28}$ Inflation was an endemic issue for many emerging economies in the last part of the twentieth century. It appears elevated, relative to tranquil times, before all types of crisis. It increases significantly afterward as any constraint on looser monetary policy disappears after a currency crisis, or as the temptation to inflate nominal claims away proves irresistible. In the year following a currency or a banking crisis, inflation rates are 10 to 15 percent above normal times. For advanced economies, in contrast, inflation remained subdued, especially around banking crises. The contrast with the recent crisis is striking: Consumer price inflation in emerging economies, although increasing between 2003 and 2008 as a result of the rapid increase in food and commodity prices, has remained significantly below the tranquil-rime average after 2008 .

Next we investigate the public finances. The top panel of figure 3 reports our estimates for the dynamics of gross public debt (as a fraction of GDP) around crises. ${ }^{29}$ While many estimates are statistically insignificant or borderline, the overall patterns presents some notable features for emerging and advanced economies alike. First, the fiscal position is estimated to worsen substantially in the aftermath of any crisis, for both country groups. The ratio of public debt to GDP increases most dramatically for advanced country banking crises (27.2

\footnotetext{
${ }^{28}$ Because some countries in our sample experienced high or even hyper inflations, we estimate equation (1) using median regression. Notably, Argentina, Brazil, Peru, Belarus, Kazakhstan, Ukraine, Bulgaria, Croatia, Macedonia, and Slovenia all experienced annual inflation rates in excess of of 1,000 percent at some point in our sample. The standard errors on the median regression were constructed by bootstrap.

${ }^{29}$ Data on public debt refer to either central or general government debt, as collated by Reinhart and Rogoff (2009). See appendix B for details.
} 
percent of GDP between $t-1$ and $t+5)$, with the next most dramatic effect being after EME currency crises (9.2 percent of GDP). A number of channels are probably responsible for the advanced country deterioration. First, government bailouts of insolvent domestic financial sectors constitute direct fiscal costs. Second, as the economy slows down markedly in the aftermath of crisis, the ratio of public debt to GDP tends to increase both for mechanical reasons - the denominator in the ratio decreases - but also because of rapidly growing public deficits, themselves the result of additional outlays and lost revenues. ${ }^{30}$ In the case of EME currency crises, devaluation or depreciation raises the home-currency value of public debt denominated in foreign currency, worsening the fiscal position through an adverse valuation effect. There is little evidence, however, that measured public debts are especially high prior to pre-2008 crises.

Consider now the 2008 crisis. While emerging countries started the 2000s with relatively high public debt levels, the period from 2003 to 2008 was one of rapid fiscal consolidation, with an improvement in the ratio of public debt to GDP representing 11.2 percent of output between 2003 and 2008. On average, emerging economies approached the crisis in a position of unprecedented fiscal strength, allowing them to apply countercyclical fiscal stimulus when needed much more freely than in the past. The fiscal health of the advanced economies, however, was significantly stretched even before the crisis, with a public debt in excess of baseline values by about 10 percent of GDP. The subsequent deterioration in fiscal position, by an additional double-digit percentage of GDP (14.2 percent between 2008 and 2010), is threatening the sustainability of a number of industrial countries' public debts. Examining public deficits rather than debts (not reported), we find a similar pattern.

The bottom part of figure 3 reports our estimates for the real interest rate, measured

\footnotetext{
${ }^{30}$ Our estimates indicate that for advanced economies, the public deficit worsens on average by 9 percent of GDP following a banking crisis.
} 
as the ex post real rate on three-month treasury bills. ${ }^{31}$. Contrary to some theories of the financial boom-crash cycle, we find little statistically significant evidence that crises before the 2008 one were preceded by periods of historically low real interest rates, except perhaps a few years prior to EME banking crises. ${ }^{32}$ In the recent period, however, interest rates have been historically and persistently low for both EMEs and advanced economies, between 2.4 and 5.2 percent below baseline for EMEs and 1.2 and 2.5 percent for advanced economies. While prior episodes of low real interest rates may have fueled consumption and borrowing bonanzas in EMEs, laying the groundwork for a subsequent crisis, this does not seem to have been the case this time around. Perhaps the recent period of low interest rates helped various EME agents, public and private, to strengthen their balance sheets. We have already documented the behavior of government debt.

We now turn to the evolution of two measures of leverage, internal and external. Our measure of internal leverage is the ratio of domestic credit to output. Based on data availability, our preferred measure of domestic credit consists of the total claims of depository corporations, minus net claims on central government, as collected in the International Monetary Fund's International Financial Statistics (IFS). ${ }^{33}$ For economies with simple financial systems, the outstanding credit to GDP ratio is likely to be a good proxy for total bank assets (cf. Table 2). The top panel of figure 4(a) reports our estimates. Two main results are apparent. First, past banking crises were associated with significant build-ups in

\footnotetext{
${ }^{31} \mathrm{As}$ for inflation, we estimate a median regression for the real interest rate

${ }^{32}$ Of course, we are using ex post measures of the real rate of interest. Given the higher and more variable ex post inflation rates (over time and across countries) that prevailed in the past in EMEs, it is inevitably difficult to produce tight estimates. The contrast with the generally low-inflation period leading up to 2008 is striking.

${ }^{33}$ While excluding claims on the central government, our measure of credit includes claims on state and local governments. As discussed in detail in appendix B, we also correct the domestic credit data for a few spurious jumps arising from changes in data coverage.
} 
credit relative to GDP. ${ }^{34}$ At its peak, excess credit represents 25 percent of output prior to advanced country banking crises, and 8.6 percent for EMEs. Second, while the level of excess credit in the years prior to the recent crisis was of a similar magnitude for advanced countries, the build-up was more dramatic in the more recent episode (24.8 percent, as compared to 9.3 percent in earlier advanced economies banking crises. While the build-up for emerging economies also seems significant (peaking at 6.3 percent of GDP), it is entirely concentrated in the Central and Eastern European countries while other emerging regions display no significant increase in credit to GDP (see panel (b) of figure 7). Emerging Europe also fared particularly poorly in the crisis, as we have seen. Within that region, increases in domestic credit are widespread and particularly pronounced in Bulgaria, Estonia, Latvia, Lithuania and Slovenia. We conjecture that the explosion in domestic credit in most of these countries is intimately tied to the process of their integration into the European Union and the adoption of the euro. ${ }^{35}$

Next we turn to our measure of external leverage. By analogy with the balance sheet of a financial institution, we propose to define external leverage as the ratio of a country's total assets to its gross equity liabilities (domestic and foreign). High leverage indicates that a country is financing a large portion of its asset holdings through external debt issuance. ${ }^{36}$

Figure 4(b) reports our estimates of external leverage, based on the updated Lane and Milesi-Ferretti (2007) data on gross external positions (which extend through 2007). While external leverage appears to have been high prior to earlier emerging market default and currency crises, it was marginally below the tranquil-times baseline in the most recent crisis.

\footnotetext{
${ }^{34}$ That the build-up is larger for advanced economies is not surprising, given these countries' higher level of financial development.

${ }^{35}$ EU membership was an advantage to these countries once the crisis broke, since even those not in the euro zone benefited from central EU sources of financial support, as well as support from Sweden, whose banks were heavily invested in emerging Europe.

${ }^{36}$ Appendix A provides details on the construction of our measure of external leverage.
} 
Advanced economies, on the other hand, show an elevated and increasing level of external leverage before 2008. By 2007, the deviation from tranquil times indicates that through foreign borrowing, each unit of domestically owned equity was leveraged 32 percentage points more than in tranquil times.

To summarize our findings so far: we see several dimensions along which emerging markets became more resilient, relative to advanced economies, in the years prior to the recent global crisis. On the macroeconomic side, they achieved price stability and a sounder fiscal position. On the financial side, with the exception of some Central and Eastern European countries, EMEs did not sharply increase domestic leverage, despite relatively low real interest rates. They also maintained historically low levels of external leverage. In contrast, fiscal conditions in advanced economies deteriorated markedly prior to the crisis, reducing the fiscal space for the authorities to respond. At the same time, advanced countries' domestic and external leverage levels increased markedly.

The top panel of figure 5 reports the evolution of the current account surplus relative to output. We observe a significant improvement in the current account in the aftermath of defaults and currency crises, especially for emerging market economies (around 3.5 percent of output). For EMEs, the sharp current account reversals associated with sudden stops are evident. Perhaps surprisingly, the largest and most persistent current account deficits seem to appear prior to advanced countries' systemic banking crises (estimated at -4.3 percent). For the recent crisis, the estimates indicate that emerging markets were running, on average, larger surpluses relative to tranquil times (around 2.2 percent of GDP). Current account balances generally decline, on average, as the crisis approaches and then bounce back to higher surpluses in 2009 as spending falls. ${ }^{37}$

\footnotetext{
${ }^{37}$ Of course, not all countries can be above average since the world's current account sums to zero by definition. However, since our estimates are unweighted, our results are consistent with a few large countries
} 
The bottom panel of figure 5 reports the log real exchange rate, with trend estimated and removed through an HP filter in a procedure identical to that used to estimate output gap. (In the figures, an increase in the real exchange rate is a real depreciation of the domestic currency.) Both defaults and currency crises in EMEs are associated with significant real depreciations (for currency crises 22 percent), and are preceded by real appreciations relative to tranquil times (around 8 percent). These currency movements are larger and more abrupt than those generally observed for advanced countries, although the latter group displays the same general pattern (including significant real appreciation prior to crises). In 2008, by contrast, we notice smaller movements in real exchange rates, for either country group, although EME exchange rates were generally stronger (compared to tranquil times) ahead of the crisis, in part a result of buoyant commodity prices. ${ }^{38}$

Figure 6 shows the behavior of two variables that have been prominent in discussions of crisis effects on EMEs: foreign exchange reserves and short-term external debt (both relative to output). For EMEs and advanced countries alike, but most markedly for the former, reserves (upper panel) are low prior to currency crises and tend to be rebuilt afterward. They fall prior to default crises but then continue downward, presumably as alternative external finance sources dry up. The large buildup of EME reserves prior to the 2008 crisis is evident (10.9 percent above baseline in 2007), as is the fall in EME reserves in 2008 itself and the subsequent return to rapid accumulation (12.4 percent above baseline by 2009). World Bank data on short-term foreign debt are available only for EMEs. Levels appear such as the U.S. running large deficits, while many other countries are in balance or surplus. In addition, a large statistical discrepancy characterizes global current account data for the mid-2000s: The world as a whole appears to be substantially in surplus.

${ }^{38}$ The real exchange rates shown are bilateral rates against a "canonical" central currency. See appendix B for details. The unavailability of multilateral effective rates for most countries dictated this choice. Thus, for the advanced countries, the 2008 depreciation shown in panel (b) of figure 5 does not include the behavior of the U.S. dollar (whose real exchange rate against itself is constant). 
elevated before defaults and currency crises, as well as the 2008 crisis, but the marginal increase in prior debt associated with default crises per se is rather small and insignificant. It is notable that after banking crises, short-term debts seem to rise. Shortening of maturities could reflect an unwillingness of foreign lenders to extend longer-term credits after a banking crisis.

In figure 7 we look more closely at an emerging region hit particularly hard by the 2008 crisis, Central and Eastern Europe (CEE), and we compare it to an average of other EMEs. CEE had a bigger output boom and a much bigger crash (panel (a)). It had a much bigger domestic credit boom (panel (b)). Its external leverage was high relative to tranquil times and rose, whereas it was low and stationary relative to tranquil times in other EMEs (panel (c)). For emerging Europe, the current account was in deficit relative to tranquil times prior to the crisis, while it was in surplus elsewhere in the emerging world, and there was a dramatic move from deficit to surplus in 2009 (panel (d)). The CEE countries, but not other EMEs, show a high and rising ratio of short-term foreign debt to GDP prior to 2008 (panel (e)). Finally, CEE real exchange rates (expressed as deviations from trend) appear quite competitive initially and appreciate between 2003 and 2008, before depreciating after 2008 as a result of nominal depreciation and/or deflation (panel(f)). By contrast, for the remaining EMEs, many of which export primary commodities, detrended real exchange rates appeared be strong relative to tranquil times and to strengthen further in the years leading to the crisis. With the exception of the real appreciation indicator, the CEE countries thus appear markedly more vulnerable than other EMEs on a range of standard fragility measures. Thus, the greater output cost they bore is consistent with theory. ${ }^{39}$ Other recent empirical

\footnotetext{
${ }^{39}$ Of course, there is heterogeneity among CEE countries, both in preconditions and in policy response, so one must be cautious in generalizing. The Baltic countries, for example, maintained fixed exchange rates against the euro throughout the crisis. That choice contributed to especially big output declines, as well as substantial internal deflation. It seems likely that fixed exchange rates also promoted the prior domestic
} 
work on the incidence of the crisis, which we describe in section 2.4, generally supports this conclusion.

\subsection{What Determines Crises?}

The preceding results emphasize that many crisis episodes were preceded by significant buildups in domestic credit as well as large real appreciations of the currency. Of course, as a matter of logic, it does not necessarily follow that countries collapse every time credit growth is high or every time the currency appreciates sharply. Similarly, while we fail to find any evidence that crises prior to 2008 were preceded by periods of elevated public debt, it is very possible that high levels of public debt increase a country's vulnerability. In addition, while suggestive, our event-study results do not always allow us to assess statistical significance with confidence. To explore these questions more systematically, we estimate panel discretechoice models with country fixed effects. Discrete choice models are commonly used in the "early-warning" literature on crisis prediction. ${ }^{40}$

As in Bussière and Fratzscher (2006), we focus on the occurrence of a crisis in a given window, not its particular timing. That is, for each type of crisis $j$ and period $t$, we define a forward looking indicator variable $y_{j t}^{k}$ that takes the value 1 if a crisis (of type $j$ ) occurs between periods $t+1$ and $t+k$, and 0 otherwise. We vary $k$ between 1 and 3 years. Our benchmark specification assumes a panel logit model with country fixed-effects, ${ }^{41}$ in which the crisis probability depends on a vector $x$ of macroeconomic variables:

$$
P\left(y_{j}^{k}=1 \mid x\right)=\frac{e^{x^{\prime} \gamma_{j}^{k}}}{1+e^{x^{\prime} \gamma_{j}^{k}}} .
$$

credit booms in the Baltics, contributing in an ex ante sense to the severity of the subsequent collapse.

${ }^{40}$ See, among others, Eichengreen et al. (1995), Frankel and Rose (1996), Berg and Pattillo (1999), Bussière and Fratzscher (2006), and Chamon et al. (2012).

${ }^{41}$ Essentially identical results come from a panel probit specification. 
Following Demirgüç-Kunt and Detragiache (2000), we drop crisis observations as well as the post-crisis observations for four years afterward, so as to avoid the post-crisis bias discussed in Bussière and Fratzscher (2006). ${ }^{42}$ We estimate the model over the full sample, 1973 to 2010. ${ }^{43}$ Table 3 reports the estimates for advanced economies and Table 4 the estimates for EMEs. We consider the following potential precursors of crises: the ratio of public debt to output, the ratio of domestic credit to output, the ratio of the current account balance to output, the real exchange rate, and the output gap, the last two expressed as percentage deviations from trends as discussed in the previous section. In addition, we consider the following variables for emerging economies: official reserves and short term external debt, both relative to output. Each table reports the overall probability of crisis occurrence $p(y=1)$ evaluated at the pre-crisis sample mean; ${ }^{44}$ for each explanatory variable $x_{i}$ in the vector $x$, its standard deviation $s d .\left(x_{i}\right)$ over the pre-crisis sample; and the marginal effect $\partial p / \partial x_{i}=p\left(x_{i}\right)\left(1-p\left(x_{i}\right)\right) \gamma_{i}$ along with White-robust standard errors, evaluated at the pre-crisis sample mean. ${ }^{45}$ Finally the column labeled $\Delta p$ reports the change in probability

\footnotetext{
${ }^{42}$ For example, public debt tends to rise sharply right after crises. From this fact one might erroneously conclude that relatively low public debt levels make crises more likely.

${ }^{43}$ To do so, we extend the list of default, banking crisis, and currency crisis events to the years 20032010 as described in appendix C. This adds six external default episodes (Uruguay in 2003, Nigeria in 2004, Dominican Republic and Venezuela in 2005, Ecuador in 2008 and Jamaica in 2010); 21 banking crises, mostly in advanced economies (the U.K. and the U.S. in 2007; Austria, Belgium, Denmark, France, Germany, Greece, Iceland, Ireland, Netherlands, Portugal, Spain, Sweden, and Switzerland in 2008, the Dominican Republic in 2003, Kazakhstan, Latvia, Russia, Slovenia, and Ukraine in 2008); and nine currency crises (Dominican Republic, Egypt, and Iraq in 2003, Iceland, Korea, Pakistan, South Africa and Turkey in 2008, Belarus in 2009). The set of additional banking crisis episodes includes 'borderline' systemic crisis under the Laeven and Valencia (2010) classification, since some of the recent crisis episodes, such as Spain, Portugal, France or Greece, may yet have to play out fully.

${ }^{44}$ To be specific, this is the predicted probability of crisis, evaluated at the pre-crisis sample mean of the explanatory variables. The pre-crisis sample, for a given type of crisis, excludes crisis years as well as the following four years.

${ }^{45}$ The standard deviation of each variable is obtained from the residual of a regression on country fixed effects, so as to remove differences in average levels of each variable across countries. White-robust standard errors correct for heteroscedasticity in the residuals. If there are omitted serially correlated determinants of crises, then our standard errors might be underestimates.
} 
resulting from a one-standard deviation increase in $x$, evaluated at the pre-crisis sample mean, $\Delta p=p\left(x_{i}+s d .\left(x_{i}\right)\right)-p\left(x_{i}\right)$, with the corresponding standard error evaluated by the delta method, also at the pre-crisis sample mean.

We notice first that the model of banking crises for advanced economies (Table 3, panel A) performs relatively poorly. While the logit parameters (not reported), and therefore the effect of the variables on the log odds ratio, are often significant, the marginal effects remain economically and statistically negligible, except for domestic credit and public debt, in large part because of the very low frequency of systemic banking crises in most of the advanced sample (only five occurrences between 1973 and 2006).

For advanced economy currency crises, the model performs relatively well. The real exchange rate emerges consistently as a significant predictor. A real currency depreciation of 7 percent (one standard deviation) reduces significantly the unconditional probability of crisis at the three-year horizon, from 8.8 percent to 3.3 percent. ${ }^{46}$ At a three-year horizon, three other variables play a significant role: domestic credit, the current account, and public debt. An increase in domestic credit above trend significantly increases the chances of a currency crisis within three years. The effect is sizable, with a one-standard deviation change (an increase of 23 percent of GDP) increasing the predicted probability of crisis in the following three years, evaluated at the pre-crisis sample mean, from 8.8 percent to 11.9 percent. A larger current account surplus reduces somewhat the likelihood of a currency crisis, although the effect is modest. A 3.9 percentage point improvement in the current account balance (as a fraction of output) reduces crisis probabilities only from 8.8 to 7 percent. Perhaps surprisingly, the estimates indicate that higher levels of public debt predict a decreased

\footnotetext{
${ }^{46}$ Of course, given the nonlinear shape of the logit functional form, and the relatively rare occurrence of crises in sample, the positive effect of a real appreciation on the probability of crisis would be significantly larger.
} 
chance of a currency crisis.

The results from Table 4 for EMEs are consistently strong. Across all types of crisis, three variables play a statistically and economically significant role: the ratio of domestic credit to output, the real exchange rate, and the ratio of official reserves to output. ${ }^{47}$ It is striking, in particular, to observe that the marginal effect of a higher domestic credit-GDP ratio is almost always smaller in magnitude and opposite in sign to the coefficient on official reserves. For instance, for banking crises at a three-year horizon, the marginal effects are 0.468 percent for credit, and -1.099 for reserves. This finding provides some justification for prudential policies that seek to accumulate official reserves as a buffer against financial fragility resulting from excessively rapid domestic credit growth, as suggested by Obstfeld et al. (2010). ${ }^{48}$

The coefficients on credit, the real exchange rate, and reserves are always economically large. A one standard deviation increase in the credit-GDP ratio (around 9 percent), increases the probability of default over the next three years by 11.5 percent, of banking crisis by 6.4 percent, and of currency crisis by 9.4 percent. Similarly a one-standard deviation depreciation of the real exchange rate (around 19 percent) reduces the same probabilities by 4.3 percent, 4.7 percent, and 2.5 percent respectively. Short term debt clearly matters for default episodes. A relatively modest 5 percentage point increase in short term debt (relative to GDP) increases the probability of default by 6.4 percent at a three-year horizon. Finally, the output gap matters only for banking crises, where a 4 percent increase in output above potential yields a 7.3 percent increase in the probability of a banking crisis over the

\footnotetext{
${ }^{47}$ Frankel and Saravelos (2010), who survey a large number of earlier empirical studies on crisis prediction, identify reserves and currency overvaluation as the two most consistently important predictors in a body of work spanning developed as well as developing countries. They also identify a significant role for domestic credit.

${ }^{48}$ Countries may be unable to control their reserve levels just prior to a crisis, because reserves tend to fall as capital flees, so it is perhaps not surprising that reserves have predictive power.
} 
following three years. The finding is suggestive of a boom-bust cycle over the sample period as a whole.

The panel logit estimates yield statistically and economically significant probability effects of several key variables. The results are consistent with our event-study analysis and indicate that several of the macro indicators that appear elevated before crises, notably domestic credit and real currency strength, also contain significant predictive power for the occurrence of crises. As a further check on the robustness of our results, we estimated the model for the period preceding the global financial crisis, from 1973 to 2002. We then used those estimates to calculate, out of sample, the one-year-ahead average predicted probability of crisis for emerging and advanced countries between 2003 and 2009. ${ }^{49}$ The predicted probability of currency crisis increased for emerging economies from 9.3 percent in 2003 to 20.3 percent in 2009 and somewhat more modestly for advanced countries from 5.7 to 13.1 percent. ${ }^{50}$ By contrast, the probability of a banking crisis for EMEs remained consistently low: between 1.8 in 2003 and 4.8 percent in 2009, after decreasing from 13 percent in 1995, a finding that is consistent with the increased resilience of emerging economies documented in this paper. The out-of-sample probability of banking crisis for advanced economies, on the other hand, soared from 8 percent in 2003 to 72 percent in $2009 !^{51}$ The prime drivers of this increasing financial fragility of advanced economies relative to emerging ones were the rapid growth of domestic credit and of public debt in advanced countries, as well as the rapid accumulation of official reserves by emerging countries.

\footnotetext{
${ }^{49}$ These results are available upon request.

${ }^{50}$ The increased probability for EMEs comes from the increase in domestic credit to GDP for these countries from 3 percent below trend to 4 percent above trend. For advanced countries, while the increase in domestic credit was larger, the estimates for the pre-2003 period indicate that this variable has a smaller effect on currency crisis probabilities, as in Table 3.

${ }^{51}$ The predicted probability of default for EMEs also remained low, around 4 percent between 2003 and 2009 .
} 


\subsection{Related Empirical Research}

A number of econometric studies, conducted as the crisis unfolded and during the course of recovery, have attempted to link crisis severity in individual countries to various macroeconomic characteristics and preconditions. Some of the studies also attempt to ascertain the nature of the shocks hitting different economies. ${ }^{52}$ Are the findings in these papers consistent with the conclusions of our own comparisons of crisis experience across country groups and across time?

The preceding studies generally differ from each other in the country groups they study, in their measurement of declines in economic activity, and in the period over which economic decline is measured. Moreover, they all face the difficulty of accurately controlling for a variety of relevant differences across diverse groups of economies. Nonetheless, a few factors stand out as predictors of crisis intensity in several of the exercises. Among the variables that appear important in several studies are prior financial liberalization, prior current account deficits, short-term external debt levels, and prior domestic credit growth. ${ }^{53}$ These findings match theoretical expectation. A liberalized financial system that is lending heavily is likely more susceptible to a crash if financial supervision is week. A country that is borrowing abroad to support home expenditure is vulnerable to a sudden stop, which will be magnified if short-term foreign debts simultaneously cannot be renewed.

It seems reasonable that a larger stock of international reserves would have mitigated

\footnotetext{
${ }^{52}$ A partial list of contributions includes Chamon et al. (2012), Berglöf et al. (2010), Berkmen et al. (2009), Blanchard et al. (2010), Claessens et al. (2010), Frankel and Saravelos (2010), Giannone et al. (2011), International-Monetary-Fund (2010), Lane and Milesi-Ferretti (2011), and Rose and Spiegel (2009), Rose and Spiegel (2010), Rose and Spiegel (2011).

${ }^{53}$ These broad generalizations naturally still leave individual country observations such as Germany, which suffered a banking crisis because of financial contagion, notwithstanding a large current account surplus, no real estate appreciation, and a competitive real exchange rate. The recent findings are consistent with earlier work, for example that of Gupta et al. (2007), who found that post-1970 currency crises were more likely to be contractionary for financially open economies that had experienced large capital inflows.
} 
crisis effects, as these can be spent down in the event of a sudden stop. But several studies, including Rose and Spiegel (2011), detect no role for reserves. On the contrary, Frankel and Saravelos (2010) argue that reserves affected several measures of crisis incidence, International-Monetary-Fund (2010) argues for a positive but diminishing marginal productivity of reserves, and Didier et al. (2011) find a positive role for reserves in aiding the output growth recovery between 2009 and 2010. ${ }^{54}$ It may be that many countries (notwithstanding a few exceptions such as Russia) hoarded reserves during the crisis, as suggested by the rather moderate average decline shown in the figure above. Policy makers in EMEs apparently view large reserve stocks as having been useful, if the recent resumption of rapid EME reserve accumulation is any indication.

Rose and Spiegel (2011), following up on their two earlier papers (Rose and Spiegel (2009); Rose and Spiegel (2010)), provide a useful compendium and critique of the econometric literature and findings. In particular, they provide a set of univariate regressions, for various country groupings, of different measures of output loss on some of the key vulnerability indicators stressed in the literature. Among the variables entering significantly in those regressions are credit market regulation (more regulation lessens crisis intensity); the prior current account surplus (a bigger surplus lessens crisis intensity); prior short-term foreign debt (more debt raises crisis intensity); prior real estate appreciation (more appreciation raises crisis intensity); and prior growth (but not level of) bank credit (higher growth raises crisis intensity). For example, as we saw above, countries in emerging Europe had current account deficits and credit booms, and these are empirically correlated with larger output declines in the recent recession. Rose and Spiegel find no econometric evidence that exchange rate pegs played a role but anecdotal evidence still suggests that exchange-rate flexibility

\footnotetext{
${ }^{54}$ Obstfeld et al. (2009) find an effect of reserves on currency depreciation.
} 
was an advantage. Thanks in part to maintaining fixed exchange rates (as noted above), the Baltic countries suffered especially steep declines in output (see Berglöf et al. (2010)). The current problems of peripheral euro zone countries might be mitigated if they could devalue their currencies.

The findings above are quite consistent with the most of the empirical regularities we discussed earlier, both regarding the recent global crisis and earlier ones. Rose and Spiegel (2011) go on to show, however, that the statistical significance of the preceding factors is much lower when subsets of them are entered jointly in various regressions measuring crisis intensity. To us, this does not contradict the idea that crises (especially banking crises such as prevailed over 2007-08) are generated and intensified by factors (such as financial development in an environment of lax supervision and moral hazard) that simultaneously generate a nexus of collinear responses: bigger external deficits and debt, domestic assetprice inflation, and credit booms. Thus, we view the evidence as supportive of the view that where EMEs' showed resilience in the recent crisis, this was due in part to their avoidance of excessive foreign and domestic leverage. ${ }^{55}$

\section{Conclusion}

The paper has investigated the dynamics of key macroeconomic variables before, during, and after different types of financial crisis, contrasting the experiences of advanced and emerging economies in the 2007-2009 global crisis and in earlier post-1973 crises. We find that the patterns seen in emerging and advanced economies' crises are qualitatively similar, although emerging markets have tended to suffer greater output losses during currency crises.

\footnotetext{
${ }^{55} \mathrm{An}$ interesting case study is that of Lim (2012), who documents how Korean corporations reduced leverage and increased liquidity after the 1997-98 crisis. See Cho (2012) for a more general discussion of Korean reforms after the late 1990s.
} 
The two most robust predictors of crises in general, for emerging and advanced economies alike, are domestic credit growth and real currency appreciation. Thus, financial vulnerabilities, in the form of excessive leverage, and real vulnerabilities, in the form of low international competitiveness, both seem to play important roles. Credit booms typically promote real currency appreciation, and countries that experience both simultaneously are likely to be especially susceptible to financial crisis.

Many advanced economies experienced big credit booms prior to the 2007-2009 crisis. On average, however, credit growth was more moderate in EMEs before the crisis, and those countries also have tended to recover more rapidly. But average EME behavior disguises heterogeneity among different countries. Looking across different emerging regions, we find that Central and Eastern Europe experienced very rapid domestic credit growth (accompanied by large current account deficits and short term foreign borrowing), as well as especially sharp output collapses. The view that differing susceptibility to credit booms is a central factor behind the incidence of the 2007-2009 crisis is consistent with the much longer historical experience analyzed by Schularick and Taylor (2009).

We also find a third robust determinant of EMEs' crisis probabilities: An emerging country's level of foreign exchange reserves is a statistically and economically significant factor determining the probability of future crises. Our analysis does not reveal the mechanism at work, and there is surely two-way causality. On the one hand, greater international liquidity makes an economy less vulnerable to a sudden stop; on the other, if crisis expectations rise for reasons that may be little related to reserve holdings, reserves are bound to fall sharply. Future research should aim to elucidate these channels empirically, as there remains substantial disagreement among researchers as to the role of reserves in shielding emerging economies during 2007-2009. 
The Great Depression of the 1930s resulted from an international monetary system featuring financial instability, severe and seemingly intractable global imbalances, and fixed exchange rates. The crisis of 2007-2009 likewise emerged in a setting of unstable finance and global imbalances, though only a few countries - mainly on the internal or external peripheries of the euro zone - have borne the additional burden of fixed exchange rates this time (Eichengreen and Temin (2010)).

As Díaz-Alejandro (1983) pointed out, countries in Latin America were able partially to decouple from richer countries during the 1930s by leaving the gold standard and defaulting on foreign debts. This strategy ushered in a long period of inward looking and ultimately destructive politics and policies. To the extent that emerging economies escaped the worst of the global crisis of 2007-2009, they did so in part through economic and institutional reforms that may have altered the old patterns of the twentieth century. Some of these reforms resulted in greater economic openness, although relatively low levels of financial development and financial globalization (compared to the advanced economies) may have been advantages in withstanding the forces that generated the 2007-2009 crisis. It remains to be seen if emerging economies can preserve their financial and economic stability without reducing current levels of economic openness. 


\section{References}

Acemoglu, Daron, Simon Johnson, James Robinson, and Yunyong Thaicharoen, "Institutional Causes, Macroeconomic Symptoms: Volatility, Crises and Growth," Journal of Monetary Economics, January 2003, 50 (1), 49-123.

Berg, Andrew and Catherine Pattillo, "Predicting currency crises:: The indicators approach and an alternative," Journal of International Money and Finance, August 1999, $18(4), 561-586$.

Berglöf, Erik, Yevgeniya Korniyenko, Alexander Plekhanov, and Jeromin Zettelmeyer, "Understanding the Crisis in Emerging Europe," Public Policy Review, 2010, 6 (6), 985-1008.

Berkmen, Pelin, Gaston Gelos, Robert Rennhack, and James P Walsh, "The Global Financial Crisis: Explaining Cross-Country Differences in the Output Impact," IMF Working Papers 09/280, International Monetary Fund December 2009.

Blanchard, Olivier J., Hamid Faruqee, and Mitali Das, "The Initial Impact of the Crisis on Emerging Market Countries," Brookings Papers on Economic Activity, Spring 2010, 41(2), 263-307.

Bordo, Michael, Barry Eichengreen, Daniela Klingebiel, and Maria Soledad Martinez-Peria, "Is the Crisis Problem Growing More Severe?," Economic Policy, April 2001, $16(32), 51-82$.

Boughton, James, Silent Revolution: The International Monetary Fund, 1979-1989, Washington, DC: International Monetary Fund, 2001.

Burnside, Craig, Martin Eichenbaum, and Sergio Rebelo, "Hedging and Financial Fragility in Fixed Exchange Rate Regimes," European Economic Review, 2001, 45 (7), 1151-1193.

Bussière, Matthieu and Marcel Fratzscher, "Towards a new early warning system of financial crises," Journal of International Money and Finance, 2006, 25 (6), 953-973.

Calvo, Guillermo A. and Carmen M. Reinhart, "When Capital Flows Suddenly Stop: Consequences and Policy," in Peter B. Kenen and Alexander K. Swoboda, eds., Reforming the International Monetary and Financial System, International Monetary Fund Washington D.C. 2000.

_ and _, "Fear of Floating," The Quarterly Journal of Economics, May 2002, 117 (2), $379-408$. 
Cantor, Richard and Frank Packer, "Sovereign Credit Ratings," Current Issues in Economics and Finance, June 1995, 1 (3), 1-6.

Caprio, Gerard, Daniela Klingebiel, Luc Laeven, and Guillermo Noguera, "Banking Crises Database," http://www1.worldbank.org/finance/html/database_ sfd.html, 2003. Accessed July 10, 2011.

Chambers, John, "Sovereign Defaults and Rating Transition Data, 2010 Update," Standard $\&$ Poor's Global Credit Portal, February 2011.

Chamon, Marcos, Atish Ghosh, and Jun Kim, "Are All Emerging Market Crises Alike?," in Maurice Obstfeld, Dongchul Cho, and Andrew Mason, eds., Global Economic Crisis: Impacts, Transmission, Recovery, Cheltenham, UK: Edward Elgar, 2012.

Cho, Dungchul, "Responses of the Korean Economy to the Global Economic Crisis: Another Currency Crisis?," in Maurice Obstfeld, Dongchul Cho, and Andrew Mason, eds., Global Economic Crisis: Impacts, Transmission, Recovery, Cheltenham, UK: Edward Elgar, 2012.

Claessens, Stijn, Giovanni Dell'Ariccia, Deniz Igan, and Luc Laeven, "CrossCountry Experiences and Policy Implications from the Global Financial Crisis," Economic Policy, April 2010, 25 (62), 267-93.

Corsetti, Giancarlo, Paolo Pesenti, and Nouriel Roubini, "Paper Tigers? A Model of the Asian Crisis," European Economic Review, June 1999, 43 (7), 1211-1236.

Demirgüç-Kunt, Asli and Enrica Detragiache, "Financial Liberalization and Financial Fragility," in Gerard Caprio, Patrick Honohan, and Joseph E. Stiglitz, eds., Financial liberalization: How far, how fast?, Cambridge University Press Cambridge, UK 2000, pp. $96-122$.

Díaz-Alejandro, Carlos F., "Stories of the 1930s for the 1980s," in Pedro Aspe Armella, Rudiger Dornbusch, and Maurice Obstfeld, eds., Financial policies and the world capital market: The problem of Latin American countries, University of Chicago Press Chicago, IL 1983, pp. 5-35.

_ , "Good-bye Financial Repression, Hello Financial Crash," Journal of Development Economics, February 1985, 19 (1-2), 1-24.

Didier, Tatiana, Constantino Hevia, and Sergio Schmukler, "How Resilient Were Emerging Economies to the Global Crisis?," Policy Research Working Paper 5637, World Bank April 2011. 
Dooley, Michael, "A Model of Crises in Emerging Markets," Economic Journal, 2000, 110 (1), 256-72.

Dornbusch, Rudiger, Ilan Goldfajn, and Rodrigo O. Valdés, "Currency Crises and Collapses," Brookings Papers on Economic Activity, 1995, 26 (2), 219-293.

Dow-Jones, "Dow Jones Total Stock Market Index," http://www.djindexes.com/ mdsidx/downloads/brochure_info/Dow_Jones_Total_Stock_Market_Indexes_ Brochure.pdf, 2011. Accessed June 26, 2011.

Edwards, Sebastian, "Thirty Years of Current Account Imbalances, Current Account Reversals, and Sudden Stops," IMF Staff Papers, 2004, 51(Special Issue), 1-49.

Eichengreen, Barry and Peter Temin, "Fetters of Gold and Paper," Oxford Review of Economic Policy, 2010, 26 (3), 370-84.

_, Andrew Rose, and Charles Wyplosz, "Exchange Market Mayhem: The Antecedents and Aftermath of Speculative Attacks," Economic Policy, October 1995, 0 (21), 249-96.

_ , Ricardo Hausmann, and Ugo Panizza, "Currency Mismatches, Debt Intolerance and Original Sin: Why They Are Not the Same and Why it Matters," in Sebastian Edwards, ed., Capital Controls and Capital Flows in Emerging Economies: Policies, Practices, and Consequences, Chicago, IL: University of Chicago Press, 2007, pp. 121-64.

Forbes, Kristin J. and Francis E. Warnock, "Capital Flow Waves: Surges, Stops, Flight and Retrenchment," mimeo, MIT and University of Virginia May 2011.

Frankel, Jeffrey A. and Andrew K. Rose, "Currency crashes in emerging markets: An empirical treatment," Journal of International Economics, November 1996, 41 (3-4), $351-366$.

_ and George Saravelos, "Are Leading Indicators of Financial Crises Useful for Assessing Country Vulnerability? Evidence from the 2008-09 Global Crisis," NBER Working Papers 16047, National Bureau of Economic Research June 2010.

FTSE, "FTSE Global Equity Index Series Country Classification," http://www.ftse.com/ Indices/Country_Classification/, September 2010. Accessed June 26, 2011.

Giannone, Domenico, Michele Lenza, and Lucrezia Reichlin, "Market Freedom and the Global Recession," IMF Economic Review, 2011, 59 (1), 111-35.

Glick, Reuven and Michael M. Hutchison, "Banking and Currency Crises: How Common are Twins?," in Ramon Moreno Reuven Glick and Mark M. Spiegel, eds., Financial Crises in Emerging Markets, Cambridge, UK: Cambridge University Press, 2001, pp. 3569. 
Goldstein, Morris and Philip Turner, Controlling Currency Mismatches in Emerging Markets, Washington, D.C.: Institute for International Economics, 2004.

Gourinchas, Pierre-Olivier, Rodrigo O. Valdés, and Oscar Landerretche, "Lending Booms: Latin America and the World," Economia, Spring 2001, 1 (2), 47-99.

Gupta, Poonam, Deepak Mishra, and Ratna Sahay, "Behavior of Output During Currency Crises," Journal of International Economics, July 2007, 72 (2), 428-450.

Hausmann, Ricardo, Ugo Panizza, and Ernesto Stein, "Why Do Countries Float the Way They Float?," Journal of Development Economics, December 2001, 66 (2), 387-414.

Hernandez, Leonardo and Oscar Landerretche, "Capital Inflows, Credit Booms, and Macroeconomic Vulnerability: The Cross-Country Experience," in Leonardo Hernandez and Klaus Schmidt-Hebbel, eds., Banking, Financial Integration, and International Crises, Central Bank of Chile Santiago, Chile 2002, pp. 199-233.

Honig, Adam, "Dollarization, Exchange Rate Regimes and Government Quality," Journal of International Money and Finance, March 2009, 28 (2), 198-214.

Honohan, Patrick and Daniela Klingebiel, "The Fiscal Cost Implications of an Accommodating Approach to Banking Crises," Journal of Banking $\mathscr{G}$ Finance, August 2003, 27 (8), 1539-1560.

International-Monetary-Fund, "How Did Emerging Markets Cope in the Crisis?," Mimeo, Strategy, Policy, and Review Department June 2010.

J.P.Morgan, "Index Packages," http://www.jpmorgan.com/pages/jpmorgan/investbk/ research/indexresearch/vendor/packages, 2011. Accessed June 26, 2011.

Kaminsky, Graciela L. and Carmen M. Reinhart, "The Twin Crises: The Causes of Banking and Balance of Payments Problems," American Economic Review, June 1999, 89 (3), 473-500.

_, _, and Carlos A. Végh, "When It Rains, It Pours: Procyclical Capital Flows and Macroeconomic Policies," NBER Macroeconomics Annual 2004, 2005, 19, 11-82.

King, Robert and Sergio Rebelo, "Low frequency filtering and real business cycles," Journal of Economics Dynamics and Control, 1993, 17, 207-231.

Kose, M. Ayhan and Eswar S. Prasad, Emerging markets: Resilience and growth amid global turmoil, Washington, DC: Brookings Institution Press, 2010. 
Laeven, Luc and Fabian Valencia, "Resolution of Banking Crises: The Good, the Bad, and the Ugly," IMF Working Papers 10/146, International Monetary Fund June 2010.

Lamfalussy, Alexandre, Financial crises in emerging markets: An essay on financial globalisation and fragility, New Haven, CT: Yale University Press, 2000.

Lane, Philip R. and Gian Maria Milesi-Ferretti, "The External Wealth of Nations Mark II: Revised and Extended Estimates of Foreign Assets and Liabilities, 1970-2004," Journal of International Economics, November 2007, 73 (2), 223-250.

_ and _, "The Cross-Country Incidence of the Global Crisis," IMF Economic Review, 2011, 59 (1), 77-110.

Lim, Kyung-Mook, "Structural Fundamentals of Korean Corporations: This Time Was Different," in Maurice Obstfeld, Dongchul Cho, and Andrew Mason, eds., Global Economic Crisis: Impacts, Transmission, Recovery, Cheltenham, UK: Edward Elgar, 2012.

McKinnon, Ronald I. and Huw Pill, "Credible Liberalizations and International Capital Flows: The Overborrowing Syndrome," in Takatoshi Ito and Anne O. Krueger, eds., Financial Deregulation and Integration in East Asia, Chicago, IL: University of Chicago Press, 1996, pp. 7-42.

Mendoza, Enrique G. and Marco E. Terrones, "An Anatomy of Credit Booms: Evidence from Macro Aggregates and Micro Data," NBER Working Papers 14049, National Bureau of Economic Research May 2008.

Milesi-Ferretti, Gian-Maria and Assaf Razin, "Current Account Reversals and Currency Crises," in Paul Krugman, ed., Currency Crises, Chicago, IL: University of Chicago Press, 2000, pp. 285-323.

Mishkin, Frederic, "The Dangers of Exchange-Rate Pegging in Emerging-Market Countries," International Finance, 1998, 1 (1), 81-101.

Moody's, "Sovereign Default and Recovery Rates, 1983-2008," Moody's Global Credit Policy, March 2009.

MSCI-Barra, "Index Country Membership," http://www.msci.com/products/indices/ tools/index_country_membership/, 2011. Accessed June 26, 2011.

Nicolò, Gianni De, Patrick Honohan, and Alain Ize, "Dollarization of Bank Deposits: Causes and Consequences," Journal of Banking $\&$ Finance, July 2005, 29 (7), 1697-1727. 
Obstfeld, Maurice, "Globalization, Macroeconomic Performance, and the Exchange Rates of Emerging Economies: Keynote Speech," Monetary and Economic Studies, 2004, 22 (S1), $29-55$.

_, Jay C. Shambaugh, and Alan M. Taylor, "Financial Instability, Reserves, and Central Bank Swap Lines in the Panic of 2008," American Economic Review, May 2009, $99(2), 480-86$.

_ , _, and _ , "Financial Stability, the Trilemma, and International Reserves," American Economic Journal: Macroeconomics, April 2010, 2 (2), 57-94.

Rajan, Raghuram G. and Ioannis Tokatlidis, "Dollar Shortages and Crises," International Journal of Central Banking, September 2005, 1 (2), 177-220.

Ravn, Morten O. and Harald Uhlig, "On adjusting the Hodrick-Prescott filter for the frequency of observations," The Review of Economics and Statistics, 2002, 84 (2), 371-375.

Reinhart, Carmen, "Dates for banking crises, currency crashes, sovereign domestic or external default (or restructuring)," http://terpconnect.umd.edu/ creinhar/Courses . html, 2011. Last accessed June 26, 2011.

Reinhart, Carmen M. and Kenneth S. Rogoff, This time is different: Eight centuries of financial folly, Princeton, NJ: Princeton University Press, 2009.

- and Vincent R. Reinhart, "After the Fall," in "Macroeconomic Challenges: The Decade Ahead" Federal Reserve Bank of Kansas City, Kansas City, MO 2011, pp. 17-60.

_, Kenneth S. Rogoff, and Miguel A. Savastano, "Debt Intolerance," Brookings Papers on Economic Activity, Spring 2003, 34, 1-74.

Rose, Andrew K. and Mark M. Spiegel, "Cross-Country Causes and Consequences of the 2008 Crisis: Early Warning," NBER Working Papers 15357, National Bureau of Economic Research September 2009.

_ and _, "Cross-Country Causes and Consequences of the 2008 Crisis: International Linkages and American Exposure," Pacific Economic Review, 2010, 15 (3), 340-363.

_ and _ , "Cross-Country Causes and Consequences of the Crisis: An Update," European Economic Review, 2011, 55 (3), 309-24.

Sachs, Jeffrey D., Aaron Tornell, and Andrés Velasco, "Financial Crises in Emerging Markets: The Lessons from 1995," Brookings Papers on Economic Activity, 1996, 27 (1), $147-216$. 
Schneider, Martin and Aaron Tornell, "Balance Sheet Effects, Bailout Guarantees and Financial Crises," Review of Economic Studies, 2004, 71, 883-913.

Schularick, Moritz and Alan M. Taylor, "Credit Booms Gone Bust: Monetary Policy, Leverage Cycles and Financial Crises, 1870-2008," NBER Working Papers 15512, National Bureau of Economic Research November 2009.

Stulz, René M., "The Limits of Financial Globalization," Journal of Finance, 2005, 60 (4), 1595-1638.

Sturzenegger, Federico and Jeromin Zettelmeyer, Debt Defaults and Lessons from a Decade of Crises, Cambridge, MA: The MIT Press, 2007.

Tornell, Aaron, "Lending Booms and Currency Crises: Empirical Link," in Takatoshi Ito and Anne O. Krueger, eds., Regional and global capital flows: Macroeconomic causes and consequences, Chicago, IL: University of Chicago Press, 2001, pp. 47-67. 


\section{Appendices}

\section{A Measuring External Leverage}

Consider the balance sheet of a country $i$. The asset side includes $V^{i}$, the value of domestic assets; $E^{j i}$ (resp. $D^{j i}$ ), the value of gross holdings of equity and direct investment in the rest of the world (resp. of foreign debt, loans and portfolio debt). The liability side includes $E^{i j}$ (resp. $D^{i j}$ ), the gross foreign holdings of domestic equity and direct investment (resp. domestic debt); a residual item, $W^{i}$, that measures the 'net worth' of country's residents. Consider this balance sheet as the balance sheet of a financial intermediary, that borrows abroad $\left(D^{i j}\right)$, raises equity $\left(E^{i j}\right)$ and invests in foreign $\left(E^{j i}\right.$ and $\left.D^{j i}\right)$ and domestic $\left(V^{i}\right)$ assets. Viewed as a financial intermediary, the balance sheet is particularly vulnerable when most of the assets are financed with senior claims such as debt. A measure of this vulnerability is our measure of external leverage, defined as the ratio of total assets $\left(V^{i}+E^{j i}+D^{j i}\right)$ relative to equity liabilities $\left(W^{i}+E^{i j}\right)$ :

$$
l^{i}=\frac{V^{i}+E^{j i}+D^{j i}}{W^{i}+E^{i j}}
$$

Gross external assets $A^{i}$ satisfy: $A^{i}=E^{j i}+D^{j i}$. Similarly, gross external liabilities $L^{i}$ satisfy: $L^{i}=E^{i j}+D^{i j}$ and net foreign assets are simply $N A^{i}=A^{i}-L^{i}$. Using these definitions, external leverage is:

$$
l^{i}=\frac{V^{i}+A^{i}}{V^{i}+N A^{i}+E^{i j}},
$$

A simple expression in terms of observables comes from assuming that the market value of domestic assets is a proportional to output: $V^{i}=\pi Y^{i}{ }^{56}$ A reasonable value for $\pi$ is probably somewhere between 2 and 4 and we will set $\pi=3$ for our calculations. Under this assumption, the external leverage ratio can be written as:

$$
l^{i}=\frac{\pi+A^{i} / Y^{i}}{\pi+N A^{i} / Y^{i}+E^{i j} / Y^{i}}
$$

This expression has a number of intuitive features. First, observe that because $N A^{i}+E^{i j} \leq A^{i}$, external leverage is always larger than 1 . It is exactly equal to 1 when all gross external liabilities are financed by equity: $N A^{i}=A^{i}-E^{i j}$. Second, the notion of external leverage is different from the gross or net asset position. The reason is simple: A country may have large but offsetting gross positions financed by equity. Because equity claims do not entail a fixed payment stream, and are junior to debt claims they do not threaten a country with external illiquidity or insolvency. ${ }^{57}$

\footnotetext{
${ }^{56}$ This assumption is an obvious oversimplification. Yet it is a reasonable approximation if Tobin's average $q$ is constant, since in that case the market value of domestic assets is proportional to the domestic capital stock (replacement value), which is quite stable relative to output.

${ }^{57}$ The leverage ratio is positive as long as $\pi+N A^{i} / Y^{i}+E^{i j} / Y^{i}>0$, that is, as long as the net foreign position is not too negative. Since $E^{i j} / Y^{i}>0$, the right hand side is always larger than $\pi$. So with $\pi$ between 2 and 4 , this definition would be problematic only when the net foreign asset position is below -200 to -400
} 


\section{B Data}

- Table 1: See appendix C for the list of countries and crisis.

- Table 2: IMF, Global Financial Stability Reports, September 2004-October 2010, Statistical Appendix, Table 3.

- Figure 1: IMF's October 2010 World Economic Outlook (WEO). Growth rates for 2010 are IMF forecasts. For each country grouping, the growth rate of GDP is a weighted average of constant-price GDP growth rates for individual countries, the country weights being shares of GDP (measured at purchasing power parity) in group GDP (also measured at PPP). We define a group's trend real growth rate as the average of annual growth rates over 19802010 (except for the Russian federation and Central and Eastern Europe, where we use the 1994-2010 average).

- Figure 2(a): Output Gap. Real output is constructed from nominal output in local currency units divided by the GDP deflator. Annual data on nominal GDP and GDP deflator come from the World Bank's World Development Indicators (WDI), the IMF's International Financial Statistics (IFS) and WEO databases and the Organization for Economic Cooperation and Development's (OECD) National Accounts database. The output gap is constructed with an Hodrick-Prescott filter, with a smoothing parameter set to 100.

- Figure 2(b): Inflation Rate. Rate of change of the Consumer Price Index. Source: WDI, IFS and OECD. Inflation for 2010 constructed from IMF forecasts in the October 2010 WEO.

- Figure 3(a): Gross Public Debt. Gross central government debt as a ratio to GDP from Reinhart and Rogoff (2009). When central government debt is not available, we use Gross general government debt, also from Reinhart and Rogoff (2009). Data are available at http://terpconnect.umd.edu/ creinhar/Courses.html

- Figure 3(b): Real Interest Rate. Ex post real interest rate defined as the 3-month annualized domestic treasury bill rate from IFS and the Global Financial Database (GFD), deflated by realized CPI-inflation rate over the following year.

- Figure 4(a): Domestic Credit. Domestic credit measured in domestic currency comes from the IFS. Based on availability, our benchmark data consist of total domestic claims of depository corporations (central banks and other depository corporations) - IFS line 32 - minus net claims on central government - IFS line 32an. Exceptions are as follows: Brazil (Claims on private sector and other financial corporations of other depository institutions - IFS lines $22 \mathrm{~d}+22 \mathrm{~g}$ ); Argentina, Australia and Ivory Coast (Claims on private sector and other financial

percent of GDP. 
corporations of depository institutions - IFS lines $32 \mathrm{~d}+32 \mathrm{~g}$ ); Norway (domestic credit data from Schularick and Taylor (2009)). Domestic credit divided by nominal GDP in domestic currency. Due to changes in the IFS presentation of monetary statistics as well as changes in data coverage, we visually identified 11 permanent jumps in the time series (for example, Sweden in 2001). To correct for these jumps, while allowing for low-frequency trends in financial deepening, we first adjust the credit/GDP variable after each jump by estimating a linear trend on prior observations and removing the observed residual in the period of the jump from all subsequent observations. We then construct the residuals from a regression on a linear time trend.

- Figure 4(b): External Leverage. Constructed according to equation (4). Gross external assets, gross external liabilities, gross equity and direct investment liabilities in US dollar from Lane and Milesi-Ferretti (2007). All data are divided by nominal GDP in US dollars from WDI.

- Figure 5(a): Current Account. Annual data in US dollars from IFS Balance of Payments statistics. Divided by output in US dollars from WDI.

- Figure 5(b): Real Exchange Rate. Except as noted below, the real exchange rate denotes the bilateral US dollar real exchange rate constructed as the nominal end-of-period exchange rate against the US dollar (from IFS and GFD, expressed in domestic currency units per US dollar) times the US GDP deflator and divided by the domestic GDP deflator. For members of the eurozone, CEE countries, and Ivory Coast, the real exchange rate denotes instead the bilateral real exchange rate against Germany, using the nominal exchange rate against the euro after 1999 (against the Deutschemark before that date), and the German GDP deflator. The log-deviation from trend is constructed usingh a Hodrick-Prescott filter, with the smoothing parameter set to 100 .

- Figure 6(a): Foreign Reserves. Total foreign exchange reserves in US dollars from IFS (line 1.d.d), divided by GDP in US dollars from WDI.

- Figure 6(b): Short-Term External Debt. data from the World Bank's Global Development Finance database. Divided by GDP in US dollars from WDI.

\section{List of Countries and Crises}

\section{C.1 Currency Crises.}

See Table 5. To date EME currency crises we use the criterion of Frankel and Rose (1996) - a 25 percent or greater nominal currency depreciation agains the US dollar over a year that is also a 10 percentage point increase in the annual rate of depreciation. 
For advanced economies we use the chronology of Bordo et al. (2001), which extends through 1997. After 1997 there were no true currency crises in advanced countries until 2008, notwithstanding the ersatz crises some authors have identified using mechanical criteria. We also include Iceland in 2008. ${ }^{58}$ The $2003-2010$ crisis are marked with a ${ }^{* *}$ ' in Table 5.

\section{C.2 Systemic Banking Crises.}

See Table 6. We draw our dating of systemic banking crises from Laeven and Valencia (2010). 2003-2010 crisis episodes are marked with a '*' in Table 6. This set of additional banking crisis episodes includes 'borderline' systemic crisis under the Laeven and Valencia (2010) classification, since some of the recent banking crisis may yet have to play out fully.

\section{C.3 Default Crisis.}

We draw our dating of domestic and external default episodes from Reinhart and Rogoff (2009), Cantor and Packer (1995), Chambers (2011), Moody's (2009), and Sturzenegger and Zettelmeyer (2007). 2003-2010 crisis episodes are marked with a '*' in Table 7.

\footnotetext{
${ }^{58} \mathrm{~A}$ number of advanced countries experienced a significant depreciation of their currency relative to the US dollar in 2008. Since this reflected mostly the strength of the dollar during that year, we do not classify these events as currency crisis, except for Iceland.
} 


\begin{tabular}{l|cccc} 
& Currency & Banking & Default & \# Countries \\
\hline Advanced & 43 & 5 & 0 & 22 \\
Emerging & 84 & 57 & 74 & 57 \\
Total & 127 & 62 & 74 & 79 \\
Source: Authors' calculations. & & &
\end{tabular}

Table 1: Crisis Incidence in Advanced and Emerging Economies, 1970-2006

\begin{tabular}{l|rrr} 
& 2003 & 2007 & $\begin{array}{l}\text { Change } \\
\text { (percent of GDP) }\end{array}$ \\
\hline European Union & 210.3 & 307.9 & 97.6 \\
United States & 71.0 & 81.1 & 10.1 \\
Japan & 168.4 & 230.1 & 61.7 \\
Asia & 144.2 & 151.3 & 7.1 \\
Emerging Europe & 33.6 & 66.2 & 32.6 \\
Latin American and Caribbean & 51.9 & 62.1 & 10.2 \\
Middle East and North Africa & 78.7 & 85.7 & 7.1 \\
Sub-saharan Africa & 71.3 & 78.5 & 7.1 \\
World & 136.5 & 174.6 & 38.1 \\
Source: IMF, Global Financial Stability Report, various issues.
\end{tabular}

Table 2: Commercial Bank Assets as a Percentage of GDP 


\begin{tabular}{|c|c|c|c|c|c|}
\hline \multirow[t]{2}{*}{ Panel A: Banking Crisis } & \multirow[b]{2}{*}{ sd. (x) } & \multicolumn{2}{|c|}{1 year } & \multicolumn{2}{|c|}{$1-2$ years } \\
\hline & & $\partial p / \partial x$ & $\Delta p$ & $\partial p / \partial x$ & $\Delta p$ \\
\hline Public Debt/GDP & 20.59 & $\begin{array}{r}0.006 \\
(0.007)\end{array}$ & $\begin{array}{r}0.26 \\
(0.24)\end{array}$ & $\begin{array}{r}0.028 \\
(0.020)\end{array}$ & $\begin{array}{l}1.28^{*} \\
(0.69)\end{array}$ \\
\hline Credit/GDP & 19.01 & $\begin{array}{r}0.013 \\
(0.015)\end{array}$ & $\begin{array}{r}1.38 \\
(0.96)\end{array}$ & $\begin{array}{r}0.066 \\
(0.048)\end{array}$ & $\begin{array}{l}7.64^{* *} \\
(2.26)\end{array}$ \\
\hline Current Account/GDP & 3.75 & $\begin{array}{r}0.016 \\
(0.022)\end{array}$ & $\begin{array}{r}0.08 \\
(0.12)\end{array}$ & $\begin{array}{r}0.080 \\
(0.078)\end{array}$ & $\begin{array}{r}0.44 \\
(0.47)\end{array}$ \\
\hline Real Exchange Rate & 6.78 & $\begin{array}{l}-0.003 \\
(0.007)\end{array}$ & $\begin{array}{r}-0.02 \\
(0.04)\end{array}$ & $\begin{array}{r}-0.029 \\
(0.023)\end{array}$ & $\begin{array}{r}-0.16 \\
(0.13)\end{array}$ \\
\hline Output Gap & 2.26 & $\begin{array}{r}0.057 \\
(0.078) \\
\end{array}$ & $\begin{array}{r}0.31 \\
(0.42)\end{array}$ & $\begin{array}{r}0.211 \\
(0.195) \\
\end{array}$ & $\begin{array}{r}0.89 \\
(0.86)\end{array}$ \\
\hline $\begin{array}{l}p \text { (percent) } \\
\text { N:18; NxT: } 547\end{array}$ & & 0.08 & & 0.41 & \\
\hline \multirow[t]{2}{*}{ Panel B: Currency Crisis } & & \multicolumn{2}{|c|}{1 year } & \multicolumn{2}{|c|}{$1-3$ years } \\
\hline & sd.(x) & $\partial p / \partial x$ & $\Delta p$ & $\partial p / \partial x$ & $\Delta p$ \\
\hline Public Debt/GDP & 22.19 & $\begin{array}{r}-0.025 \\
(0.029)\end{array}$ & $\begin{array}{r}-0.49 \\
(0.51)\end{array}$ & $\begin{array}{c}-0.140^{*} \\
(0.078)\end{array}$ & $\begin{array}{r}-2.66^{* *} \\
(1.27)\end{array}$ \\
\hline Credit/GDP & 22.75 & $\begin{array}{r}0.031 \\
(0.021)\end{array}$ & $\begin{array}{r}0.85 \\
(0.65)\end{array}$ & $\begin{array}{c}0.119^{*} \\
(0.062)\end{array}$ & $\begin{array}{r}3.12^{*} \\
(1.81)\end{array}$ \\
\hline Current Account/GDP & 3.86 & $\begin{array}{r}0.100 \\
(0.114)\end{array}$ & $\begin{array}{r}0.42 \\
(0.53)\end{array}$ & $\begin{array}{l}-0.508^{*} \\
(0.308)\end{array}$ & $\begin{array}{r}-1.77^{*} \\
(0.98)\end{array}$ \\
\hline Real Exchange Rate & 7.28 & $\begin{array}{r}-0.414^{* *} \\
(0.128)\end{array}$ & $\begin{array}{r}-1.51^{* *} \\
(0.66)\end{array}$ & $\begin{array}{r}-1.138^{* *} \\
(0.211)\end{array}$ & $\begin{array}{r}-5.48^{* *} \\
(0.83)\end{array}$ \\
\hline Output Gap & 2.22 & $\begin{array}{c}-0.542^{*} \\
(0.288)\end{array}$ & $\begin{array}{l}-0.89^{*} \\
(0.47)\end{array}$ & $\begin{array}{r}-0.277 \\
(0.657)\end{array}$ & $\begin{array}{r}-0.60 \\
(1.37)\end{array}$ \\
\hline $\begin{array}{l}p \text { (percent) } \\
\text { N: } 15 ; \text { NxT: } 373\end{array}$ & & 1.88 & & 8.80 & \\
\hline
\end{tabular}

Note: ${ }^{*}(*)$ : significant at $10 \%(5 \%)$. The table reports estimates of a panel logit with country fixed-effects for the occurrence of crisis at horizon $t+1: t+k$ where $k$ varies between 1 and 3. All variables in percent. Real Exchange Rate: deviation from HP-trend. Credit/GDP: deviation from linear trend. Output gap: deviation from HP-trend. $p$ : estimated probability of crisis, evaluated at the pre-crisis sample mean. sd.(x): standard deviation of variable over tranquil periods. $\partial p / \partial x$ : marginal effect (in percentage) for variable $\mathrm{x}$, evaluated at tranquil sample mean. $\Delta p=p(x+s d .(x))-p(x)$ evaluated at tranquil sample mean. Robust (White) standard errors evaluated by delta-method when necessary. N: number of crisis events; NxT: number of observations.

Table 3: Panel Logit Estimation: Advanced Economies. Sample: 1973-2010. 


\begin{tabular}{|c|c|c|c|c|c|}
\hline \multirow[t]{2}{*}{ Panel A: Default } & \multirow[b]{2}{*}{$\operatorname{sd} .(\mathrm{x})$} & \multicolumn{2}{|c|}{1 year } & \multicolumn{2}{|c|}{$1-3$ years } \\
\hline & & $\partial p / \partial x$ & $\Delta p$ & $\partial p / \partial x$ & $\Delta p$ \\
\hline Public Debt/GDP & 18.78 & $\begin{array}{r}-0.021 \\
(0.050)\end{array}$ & $\begin{array}{r}-0.37 \\
(0.86)\end{array}$ & $\begin{array}{c}-0.193^{*} \\
(0.105)\end{array}$ & $\begin{array}{r}-3.11^{* *} \\
(1.49)\end{array}$ \\
\hline Credit/GDP & 7.64 & $\begin{array}{r}0.417^{* *} \\
(0.129)\end{array}$ & $\begin{array}{l}4.89^{* *} \\
(1.70)\end{array}$ & $\begin{array}{r}1.138^{* *} \\
(0.197)\end{array}$ & $\begin{array}{r}11.49^{* *} \\
(2.44)\end{array}$ \\
\hline Current Account/GDP & 4.03 & $\begin{array}{r}0.236 \\
(0.249)\end{array}$ & $\begin{array}{r}1.08 \\
(1.27)\end{array}$ & $\begin{array}{r}0.150 \\
(0.548)\end{array}$ & $\begin{array}{r}0.63 \\
(2.36)\end{array}$ \\
\hline Reserves/GDP & 4.58 & $\begin{array}{r}-0.593^{* *} \\
(0.299)\end{array}$ & $\begin{array}{r}-1.93^{* *} \\
(0.69)\end{array}$ & $\begin{array}{r}-1.309^{* *} \\
(0.516)\end{array}$ & $\begin{array}{r}-5.15^{* *} \\
(1.56)\end{array}$ \\
\hline Real Exchange Rate & 20.60 & $\begin{array}{r}-0.052 \\
(0.032)\end{array}$ & $\begin{array}{r}-0.94^{*} \\
(0.51)\end{array}$ & $\begin{array}{r}-0.257^{* *} \\
(0.089)\end{array}$ & $\begin{array}{r}-4.26^{* *} \\
(1.24)\end{array}$ \\
\hline Short Term Debt/GDP & 5.42 & $\begin{array}{r}0.255^{* *} \\
(0.125)\end{array}$ & $\begin{array}{l}1.66^{*} \\
(0.94)\end{array}$ & $\begin{array}{r}1.010^{* *} \\
(0.270)\end{array}$ & $\begin{array}{r}6.43^{* *} \\
(1.99)\end{array}$ \\
\hline Output Gap & 3.79 & $\begin{array}{r}-0.248 \\
(0.205)\end{array}$ & $\begin{array}{r}-0.83 \\
(0.61)\end{array}$ & $\begin{array}{r}0.195 \\
(0.489)\end{array}$ & $\begin{array}{r}0.75 \\
(1.93)\end{array}$ \\
\hline $\begin{array}{l}p \text { (percent) } \\
\mathrm{N}: 17 ; \mathrm{NxT}: 360\end{array}$ & & 3.68 & & 11.82 & \\
\hline \multirow[t]{2}{*}{ Panel B: Banking Crisis } & & \multicolumn{2}{|c|}{1 year } & \multicolumn{2}{|c|}{$1-3$ years } \\
\hline & sd. $(\mathrm{x})$ & $\partial p / \partial x$ & $\Delta p$ & $\partial p / \partial x$ & $\Delta p$ \\
\hline Public Debt/GDP & 22.27 & $\begin{array}{r}0.017 \\
(0.023)\end{array}$ & $\begin{array}{r}0.41 \\
(0.58)\end{array}$ & $\begin{array}{r}0.152^{* *} \\
(0.055)\end{array}$ & $\begin{array}{l}4.01^{* *} \\
(1.68)\end{array}$ \\
\hline Credit/GDP & 10.59 & $\begin{array}{r}0.181^{* *} \\
(0.060)\end{array}$ & $\begin{array}{r}2.70^{* *} \\
(1.13)\end{array}$ & $\begin{array}{r}0.468^{* *} \\
(0.127)\end{array}$ & $\begin{array}{r}6.35^{* *} \\
(2.11)\end{array}$ \\
\hline Current Account/GDP & 5.02 & $\begin{array}{r}0.090 \\
(0.165)\end{array}$ & $\begin{array}{r}0.49 \\
(0.97)\end{array}$ & $\begin{array}{r}0.188 \\
(0.285)\end{array}$ & $\begin{array}{r}0.99 \\
(1.57)\end{array}$ \\
\hline Reserves/GDP & 6.91 & $\begin{array}{r}-0.323^{*} \\
(0.176)\end{array}$ & $\begin{array}{r}-1.55^{* *} \\
(0.61)\end{array}$ & $\begin{array}{r}-1.099^{* *} \\
(0.295)\end{array}$ & $\begin{array}{r}-5.22^{* *} \\
(1.02)\end{array}$ \\
\hline Real Exchange Rate & 19.99 & $\begin{array}{r}-0.075^{* *} \\
(0.028)\end{array}$ & $\begin{array}{r}-1.17^{* *} \\
(0.36)\end{array}$ & $\begin{array}{r}-0.326^{* *} \\
(0.073)\end{array}$ & $\begin{array}{r}-4.71^{* *} \\
(0.84)\end{array}$ \\
\hline Short Term Debt/GDP & 5.19 & $\begin{array}{r}0.083 \\
(0.108)\end{array}$ & $\begin{array}{r}0.47 \\
(0.65)\end{array}$ & $\begin{array}{l}0.334^{*} \\
(0.202)\end{array}$ & $\begin{array}{r}1.89 \\
(1.24)\end{array}$ \\
\hline Output Gap & 3.93 & $\begin{array}{r}0.334 \\
(0.206)\end{array}$ & $\begin{array}{r}1.66 \\
(1.21)\end{array}$ & $\begin{array}{r}1.414^{* *} \\
(0.415)\end{array}$ & $\begin{array}{r}7.34^{* *} \\
(2.61)\end{array}$ \\
\hline $\begin{array}{l}p \text { (percent) } \\
\mathrm{N}: 26 ; \text { NxT: } 571\end{array}$ & & 2.81 & & 8.94 & \\
\hline \multirow[t]{2}{*}{ Panel C: Currency Crisis } & & \multicolumn{2}{|c|}{1 year } & \multicolumn{2}{|c|}{$1-3$ years } \\
\hline & sd. (x) & $\partial p / \partial x$ & $\Delta p$ & $\partial p / \partial x$ & $\Delta p$ \\
\hline Public Debt/GDP & 17.17 & $\begin{array}{r}0.050 \\
(0.037)\end{array}$ & $\begin{array}{r}0.96 \\
(0.80)\end{array}$ & $\begin{array}{r}0.097 \\
(0.062)\end{array}$ & $\begin{array}{r}1.85 \\
(1.32)\end{array}$ \\
\hline Credit/GDP & 9.58 & $\begin{array}{r}0.329^{* *} \\
(0.101)\end{array}$ & $\begin{array}{r}4.99^{* *} \\
(2.29)\end{array}$ & $\begin{array}{r}0.656^{* *} \\
(0.149)\end{array}$ & $\begin{array}{r}9.36^{* *} \\
(3.07)\end{array}$ \\
\hline Current Account/GDP & 4.71 & $\begin{array}{r}0.127 \\
(0.158)\end{array}$ & $\begin{array}{r}0.65 \\
(0.88)\end{array}$ & $\begin{array}{r}0.224 \\
(0.359)\end{array}$ & $\begin{array}{r}1.13 \\
(1.93)\end{array}$ \\
\hline Reserves/GDP & 6.89 & $\begin{array}{r}-0.667^{* *} \\
(0.172)\end{array}$ & $\begin{array}{r}-2.56^{* *} \\
(0.68)\end{array}$ & $\begin{array}{r}-1.372^{* *} \\
(0.252)\end{array}$ & $\begin{array}{r}-5.36^{* *} \\
(0.94)\end{array}$ \\
\hline Real Exchange Rate & 18.15 & $\begin{array}{r}-0.023 \\
(0.033)\end{array}$ & $\begin{array}{r}-0.40 \\
(0.53)\end{array}$ & $\begin{array}{r}-0.170^{* *} \\
(0.069)\end{array}$ & $\begin{array}{r}-2.53^{* *} \\
(0.89)\end{array}$ \\
\hline Short Term Debt/GDP & 4.38 & $\begin{array}{r}0.136 \\
(0.163)\end{array}$ & $\begin{array}{r}0.65 \\
(0.84)\end{array}$ & $\begin{array}{r}0.450 \\
(0.300)\end{array}$ & $\begin{array}{r}2.23 \\
(1.66)\end{array}$ \\
\hline Output Gap & 3.78 & $\begin{array}{r}0.387^{*} \\
(0.202) \\
\end{array}$ & $\begin{array}{l}1.80^{*} \\
(1.07)\end{array}$ & $\begin{array}{r}0.451 \\
(0.288) \\
\end{array}$ & $\begin{array}{r}1.90 \\
(1.33)\end{array}$ \\
\hline $\begin{array}{l}p \text { (percent) } \\
\mathrm{N}: 26 ; \mathrm{NxT}: 381\end{array}$ & & 3.44 & & 7.21 & \\
\hline
\end{tabular}

Note: $\left.{ }^{* *}\right)$ : significant at $10 \%(5 \%)$. See table 3 for definitions.

Table 4: Panel Logit Estimation: Emerging Market Economies. Sample: 1973-2010. 
Table 5: Currency Crisis Episodes, 1973-2010.

\begin{tabular}{|c|c|c|c|}
\hline Country & Year & Source & Remarks \\
\hline \multicolumn{4}{|c|}{ Advanced Economies } \\
\hline Australia & $1976,1983,1985$ & Bordo et al. (2001) & \\
\hline Belgium & 1982 & Bordo et al. (2001) & \\
\hline Canada & 1981,1986 & Bordo et al. (2001) & \\
\hline Denmark & $1976,1992,1993$ & Bordo et al. (2001) & \\
\hline Finland & $1986,1991,1993$ & Bordo et al. (2001) & \\
\hline France & 1992 & Bordo et al. (2001) & \\
\hline Greece & 1983,1985 & Bordo et al. (2001) & \\
\hline Iceland & $1975,1978,1981,1984,2008^{*}$ & Bordo et al. (2001) & 2008: authors calculation. \\
\hline Ireland & $1976,1986,1992$ & Bordo et al. (2001) & \\
\hline Italy & $1976,1992,1995$ & Bordo et al. (2001) & \\
\hline Japan & 1979 & Bordo et al. (2001) & \\
\hline New Zealand & $1975,1978,1980,1984,1988$ & Bordo et al. (2001) & \\
\hline Norway & 1986 & Bordo et al. (2001) & \\
\hline Portugal & $1976,1978,1983$ & Bordo et al. (2001) & \\
\hline Spain & $1976,1982,1992,1995$ & Bordo et al. (2001) & \\
\hline Sweden & 1992 & Bordo et al. (2001) & \\
\hline Switzerland & 1977 & Bordo et al. (2001) & \\
\hline United Kingdom & 1976,1992 & Bordo et al. (2001) & \\
\hline Total & 44, of which 43 in 1973-2006 & & \\
\hline \multicolumn{4}{|c|}{ Emerging Economies } \\
\hline Argentina & $1975,1981,1987,2002$ & Frankel and Rose (1996) & \\
\hline Belarus & $1996,2000,2009$ & Frankel and Rose (1996) & \\
\hline Brazil & $1976,1983,1987,1992,1999,2008^{*}$ & Frankel and Rose (1996) & \\
\hline Bulgaria & 1990,1996 & Frankel and Rose (1996) & \\
\hline Côte d'Tvoire & 1994 & Frankel and Rose (1996) & \\
\hline Chile & 1975,1982 & Frankel and Rose (1996) & \\
\hline China & 1984,1994 & Frankel and Rose (1996) & \\
\hline Columbia & 1985,1997 & Frankel and Rose (1996) & \\
\hline Dominican Republic & $1985,1990,2003^{*}$ & Frankel and Rose (1996) & \\
\hline Ecuador & 1982,1995 & Frankel and Rose (1996) & \\
\hline Egypt & $1979,1989,2003^{*}$ & Frankel and Rose (1996) & \\
\hline El Salvador & 1986,1990 & Frankel and Rose (1996) & \\
\hline Georgia & 1998 & Frankel and Rose (1996) & \\
\hline India & 1991 & Frankel and Rose (1996) & \\
\hline
\end{tabular}


Table 5 continued from previous page

\begin{tabular}{|c|c|c|c|}
\hline Country & Year & Source & Remarks \\
\hline Indonesia & 1978, 1983, 1997 & Frankel and Rose (1996) & \\
\hline Iraq & $2003^{*}$ & Frankel and Rose (1996) & \\
\hline Israel & 1977,1983 & Frankel and Rose (1996) & \\
\hline Jamaica & $1978,1983,1991$ & Frankel and Rose (1996) & \\
\hline Jordan & 1988 & Frankel and Rose (1996) & \\
\hline Kazakhstan & 1999 & Frankel and Rose (1996) & \\
\hline Korea & $1980,1997,2008^{*}$ & Frankel and Rose (1996) & \\
\hline Lebanon & 1983,1990 & Frankel and Rose (1996) & \\
\hline Macedonia & 1997 & Frankel and Rose (1996) & \\
\hline Malaysia & 1997 & Frankel and Rose (1996) & \\
\hline Mexico & 1976, 1982, 1994 & Frankel and Rose (1996) & \\
\hline Nigeria & $1986,1992,1999$ & Frankel and Rose (1996) & \\
\hline Pakistan & $1982,2008^{*}$ & Frankel and Rose (1996) & \\
\hline Peru & $1976,1982,1987$ & Frankel and Rose (1996) & \\
\hline Philippines & 1983,1997 & Frankel and Rose (1996) & \\
\hline Poland & 1978, 1986, 1992 & Frankel and Rose (1996) & \\
\hline Romania & 1990,1997 & Frankel and Rose (1996) & \\
\hline Russia & 1998 & Frankel and Rose (1996) & \\
\hline Serbia & 2000 & Frankel and Rose (1996) & \\
\hline South Africa & $1984,2001,2008^{*}$ & Frankel and Rose (1996) & \\
\hline Sri Lanka & 1977 & Frankel and Rose (1996) & \\
\hline Thailand & 1997 & Frankel and Rose (1996) & \\
\hline Turkey & $1978,1988,1994,1999,2008^{*}$ & Frankel and Rose (1996) & \\
\hline Ukraine & $1998,2008^{*}$ & Frankel and Rose (1996) & \\
\hline Uruguay & $1982,1989,2002$ & Frankel and Rose (1996) & \\
\hline Venezuela & $1984,1994,2002$ & Frankel and Rose (1996) & \\
\hline
\end{tabular}

\begin{tabular}{l|l} 
Total & 91, of which 84 in 1973-2006
\end{tabular}

* indicates crisis used only in the panel logit analysis of section 2.3 of the paper 
Table 6: Systemic Banking Crisis Episodes, 1973-2010.

\begin{tabular}{|c|c|c|c|}
\hline Country & Year & Source & Remarks \\
\hline \multicolumn{4}{|l|}{ Advanced Economies } \\
\hline Austria & $2008^{*}$ & Laeven and Valencia (2010) & \\
\hline Belgium & $2008^{*}$ & Laeven and Valencia (2010) & \\
\hline Denmark & $2008^{*}$ & Laeven and Valencia (2010) & \\
\hline Finland & 1991 & Laeven and Valencia (2010) & \\
\hline France & $2008^{*}$ & Laeven and Valencia (2010) & borderline \\
\hline Germany & $2008^{*}$ & Laeven and Valencia (2010) & \\
\hline Greece & $2008^{*}$ & Laeven and Valencia (2010) & borderline \\
\hline Iceland & $2008^{*}$ & Laeven and Valencia (2010) & \\
\hline Ireland & $2008^{*}$ & Laeven and Valencia (2010) & \\
\hline Japan & 1997 & Laeven and Valencia (2010) & \\
\hline Netherlands & $2008^{*}$ & Laeven and Valencia (2010) & \\
\hline Norway & 1991 & Laeven and Valencia (2010) & \\
\hline Portugal & $2008^{*}$ & Laeven and Valencia (2010) & borderline \\
\hline Spain & $1977,2008^{*}$ & Laeven and Valencia (2010) & 2008 borderline \\
\hline Sweden & $1991,2008^{*}$ & Laeven and Valencia (2010) & 2008 borderline \\
\hline Switzerland & $2008^{*}$ & Laeven and Valencia (2010) & borderline \\
\hline United Kingdom & $2007^{*}$ & Laeven and Valencia (2010) & \\
\hline United States & $2007^{*}$ & Laeven and Valencia (2010) & \\
\hline Total & \multicolumn{3}{|c|}{20 of which 5 in 1973-2006 } \\
\hline Emerging Economies & & & \\
\hline Argentina & $1980,1989,1995,2001$ & Laeven and Valencia (2010) & \\
\hline Bosnia & 1992 & Laeven and Valencia (2010) & \\
\hline Brazil & 1990, 1994 & Laeven and Valencia (2010) & \\
\hline Bulgaria & 1996 & Laeven and Valencia (2010) & \\
\hline Côte d'Ivoire & 1988 & Caprio et al. (2003) & \\
\hline Chile & 1976,1981 & Laeven and Valencia (2010) & \\
\hline China & 1998 & Laeven and Valencia (2010) & \\
\hline Columbia & 1982,1998 & Laeven and Valencia (2010) & \\
\hline Croatia & 1998 & Laeven and Valencia (2010) & \\
\hline Dominican Republic & $2003^{*}$ & Laeven and Valencia (2010) & \\
\hline Ecuador & 1982, 1996, 1998 & Laeven and Valencia (2010) & 1986 in Caprio et al. (2003) \\
\hline Egypt & 1980 & Laeven and Valencia (2010) & \\
\hline El Salvador & 1989 & Laeven and Valencia (2010) & \\
\hline Estonia & 1992 & Laeven and Valencia (2010) & \\
\hline
\end{tabular}

continued on next page 
Table 6 continued from previous page

\begin{tabular}{|c|c|c|c|}
\hline Country & Year & Source & Remarks \\
\hline Georgia & 1991 & Laeven and Valencia (2010) & \\
\hline Hungary & 1991 & Laeven and Valencia (2010) & \\
\hline Indonesia & 1997 & Laeven and Valencia (2010) & \\
\hline Israel & 1977 & Laeven and Valencia (2010) & \\
\hline Jamaica & 1996 & Laeven and Valencia (2010) & \\
\hline Kazakhstan & $2008^{*}$ & Laeven and Valencia (2010) & borderline \\
\hline Korea & 1997 & Laeven and Valencia (2010) & \\
\hline Kuwait & 1982 & Laeven and Valencia (2010) & \\
\hline Latvia & $1995,2008^{*}$ & Laeven and Valencia (2010) & \\
\hline Lebanon & 1990 & Laeven and Valencia (2010) & \\
\hline Lithuania & 1995 & Laeven and Valencia (2010) & \\
\hline Macedonia & 1993 & Laeven and Valencia (2010) & \\
\hline Malaysia & 1997 & Laeven and Valencia (2010) & \\
\hline Mexico & 1981, 1994 & Laeven and Valencia (2010) & \\
\hline Morocco & 1980 & Laeven and Valencia (2010) & \\
\hline Nigeria & 1991 & Laeven and Valencia (2010) & \\
\hline Panama & 1988 & Laeven and Valencia (2010) & \\
\hline Peru & 1983 & Laeven and Valencia (2010) & \\
\hline Philippines & 1983, 1997 & Laeven and Valencia (2010) & \\
\hline Poland & 1992 & Laeven and Valencia (2010) & \\
\hline Romania & 1990 & Laeven and Valencia (2010) & \\
\hline Russia & $1998,2008^{*}$ & Laeven and Valencia (2010) & 2008 borderline \\
\hline Slovak Republic & 1998 & Laeven and Valencia (2010) & \\
\hline Slovenia & $1992,2008^{*}$ & Laeven and Valencia (2010) & 2008 borderline \\
\hline Sri Lanka & 1989 & Laeven and Valencia (2010) & \\
\hline Thailand & 1983,1997 & Laeven and Valencia (2010) & \\
\hline Turkey & 1982,2000 & Laeven and Valencia (2010) & \\
\hline Ukraine & $1998,2008^{*}$ & Laeven and Valencia (2010) & \\
\hline Uruguay & 1981,2002 & Laeven and Valencia (2010) & \\
\hline Venezuela & 1994 & Laeven and Valencia (2010) & \\
\hline
\end{tabular}

* indicates crisis used only in the panel logit analysis of section 2.3 of the paper 
Table 7: Default Episodes, 1973-2010.

\begin{tabular}{|c|c|c|c|}
\hline Country & Year & Source & Remarks \\
\hline \multicolumn{4}{|c|}{ Emerging Economies } \\
\hline \multirow[t]{3}{*}{ Argentina } & 1982 & Reinhart (2011) & Domestic and external \\
\hline & 1989 & Reinhart (2011) & Domestic \\
\hline & 2001 & Reinhart (2011) & External \\
\hline \multirow[t]{4}{*}{ Brazil } & 1983 & Reinhart (2011) & External \\
\hline & 1986 & Reinhart (2011) & Domestic \\
\hline & 1990 & Reinhart (2011) & Domestic \\
\hline & 2002 & Reinhart (2011) & Domestic and external \\
\hline Bulgaria & 1990 & Reinhart and Rogoff (2009, p.23) & External \\
\hline \multirow[t]{2}{*}{ Côte d'Ivoire } & 1983 & Reinhart (2011) & External \\
\hline & 2000 & Reinhart (2011) & External \\
\hline \multirow[t]{2}{*}{ Chile } & 1974 & Reinhart (2011) & External \\
\hline & 1983 & Reinhart (2011) & External \\
\hline Croatia & 1993 & Reinhart and Rogoff (2009, p.115) & Domestic \\
\hline \multirow[t]{3}{*}{ Dominican Republic } & 1975 & Reinhart (2011) & Domestic \\
\hline & 1982 & Reinhart (2011) & External \\
\hline & $2005^{*}$ & Reinhart (2011) & External \\
\hline \multirow[t]{3}{*}{ Ecuador } & 1982 & Reinhart (2011) & External \\
\hline & 1999 & Reinhart (2011) & Domestic and external \\
\hline & $2008^{*}$ & Reinhart (2011) & External \\
\hline Egypt & 1984 & Reinhart (2011) & External \\
\hline El Salvador & 1981 & Reinhart (2011) & Domestic \\
\hline \multirow[t]{2}{*}{ India } & 1973 & Reinhart (2011) & External. \\
\hline & & & Default started in 1972. \\
\hline \multirow[t]{3}{*}{ Indonesia } & 1997 & Reinhart (2011) & Domestic \\
\hline & 1998 & Reinhart (2011) & External \\
\hline & 2002 & Reinhart (2011) & External \\
\hline Iraq & 1990 & Reinhart and Rogoff (2009, p.23) & External \\
\hline \multirow[t]{2}{*}{ Jamaica } & 1978 & Reinhart and Rogoff (2009, p.23) & External \\
\hline & $2010^{*}$ & Chambers (2011) & External \\
\hline Jordan & 1989 & Reinhart and Rogoff (2009, p.23) & External \\
\hline Kuwait & 1990 & Reinhart and Rogoff (2009, p.115) & Domestic \\
\hline Mexico & 1982 & Reinhart (2011) & Domestic and external \\
\hline \multirow[t]{2}{*}{ Morocco } & 1983 & Reinhart (2011) & External \\
\hline & 1986 & Reinhart (2011) & External \\
\hline Nigeria & 1982 & Reinhart (2011) & External \\
\hline
\end{tabular}


Table 7 continued from previous page

\begin{tabular}{|c|c|c|c|}
\hline Country & Year & Source & Remarks \\
\hline \multirow{4}{*}{ Pakistan } & 2001 & Reinhart (2011) & External \\
\hline & $2004^{*}$ & Reinhart (2011) & External \\
\hline & 1981 & (Sturzenegger and Zettelmeyer, 2007, Table 1) & External \\
\hline & 1999 & Chambers (2011) & External \\
\hline \multirow[t]{3}{*}{ Panama } & 1983 & Reinhart (2011) & External \\
\hline & 1987 & Cantor and Packer (1995) & External \\
\hline & 1988 & Reinhart (2011) & Domestic \\
\hline \multirow[t]{5}{*}{ Peru } & 1976 & Reinhart (2011) & External \\
\hline & 1978 & Reinhart (2011) & External \\
\hline & 1980 & Reinhart (2011) & External \\
\hline & 1984 & Reinhart (2011) & External \\
\hline & 1985 & Reinhart (2011) & Domestic \\
\hline Philippines & 1983 & Reinhart and Rogoff (2009, p.115) & External \\
\hline Poland & 1981 & Reinhart (2011) & External \\
\hline \multirow[t]{2}{*}{ Romania } & 1981 & Reinhart (2011) & External \\
\hline & 1986 & Reinhart (2011) & External \\
\hline \multirow[t]{3}{*}{ Russia } & 1991 & Reinhart (2011) & External \\
\hline & 1993 & Cantor and Packer (1995) & Domestic \\
\hline & 1998 & Reinhart (2011), Reinhart and Rogoff (2009, p.23) & Domestic and external \\
\hline \multirow[t]{2}{*}{ Serbia } & 1983 & Cantor and Packer (1995) & External (Yugoslavia) \\
\hline & 1992 & Cantor and Packer (1995) & External (Yugoslavia) \\
\hline \multirow[t]{3}{*}{ South Africa } & 1985 & Reinhart (2011) & External \\
\hline & 1989 & Reinhart (2011) & External \\
\hline & 1993 & Reinhart (2011) & External \\
\hline \multirow[t]{3}{*}{ Sri Lanka } & 1979 & Reinhart (2011) & External \\
\hline & 1981 & Reinhart (2011) & External \\
\hline & 1996 & Reinhart (2011) & Domestic \\
\hline Tunisia & 1979 & Reinhart (2011) & External \\
\hline \multirow[t]{3}{*}{ Turkey } & 1978 & Reinhart (2011) & External \\
\hline & 1982 & Reinhart (2011) & External \\
\hline & 2001 & Reinhart (2011) & Domestic and external \\
\hline \multirow[t]{2}{*}{ Ukraine } & 1998 & Reinhart and Rogoff (2009, p.115), Moody's (2009) & Domestic and external \\
\hline & 2000 & Moody's (2009) & External \\
\hline \multirow[t]{4}{*}{ Uruguay } & 1983 & Reinhart (2011) & External \\
\hline & 1987 & Reinhart (2011) & External \\
\hline & 1990 & Reinhart (2011) & External \\
\hline & $2003^{*}$ & Reinhart (2011) & External \\
\hline Venezuela & 1982 & Reinhart and Rogoff (2009, p.23) & External \\
\hline
\end{tabular}

continued on next page 
Table 7 continued from previous page

\begin{tabular}{l|lll} 
& & & \\
Country & Year & Source & Remarks \\
\hline & 1990 & Reinhart (2011) & External \\
& 1990 & Reinhart (2011) & Domestic and external \\
& 1995 & Reinhart (2011) & External \\
& 1998 & Reinhart and Rogoff $(2009$, p.115) & Domestic \\
& $2005^{*}$ & Chambers (2011) & External \\
\hline
\end{tabular}

\begin{tabular}{l|l} 
Total & 76, of which 74 in $1973-2006$
\end{tabular}

* indicates crisis used only in the panel logit analysis of section 2.3 of the paper 
(a) Emerging Asia

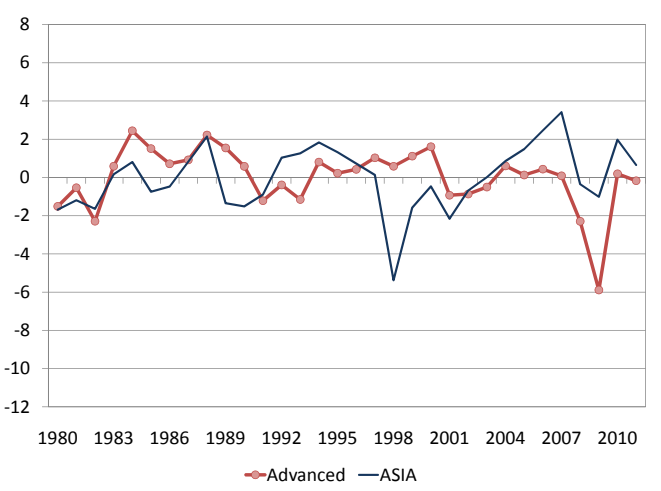

(c) Emerging Middle East \& North Africa

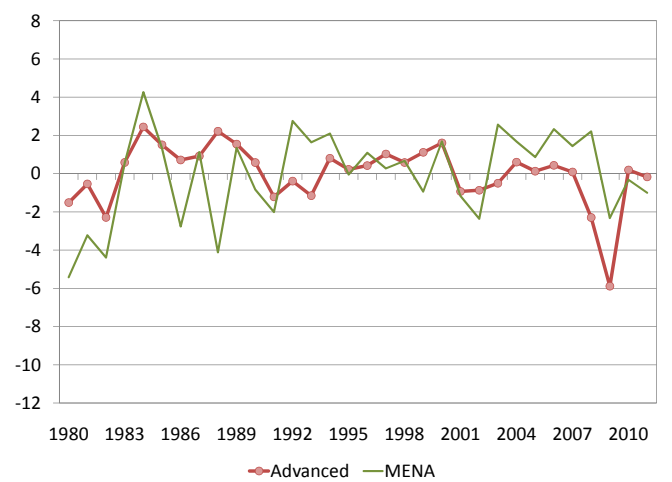

(b) Emerging Latin America

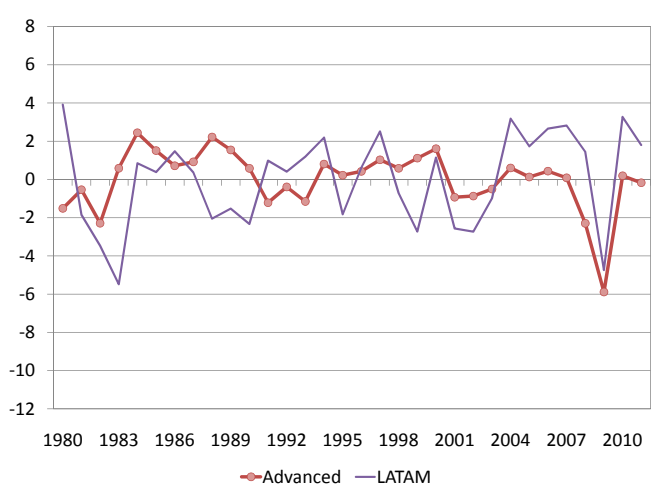

(d) Emerging Sub-Saharan Africa

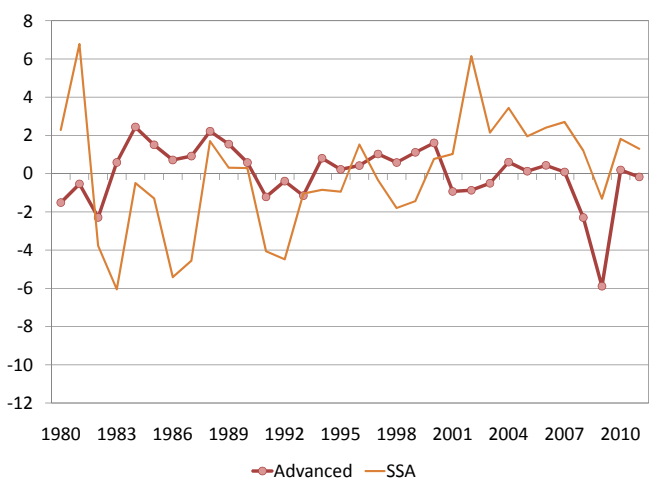

(e) Emerging Central \& Eastern Europe \& CIS

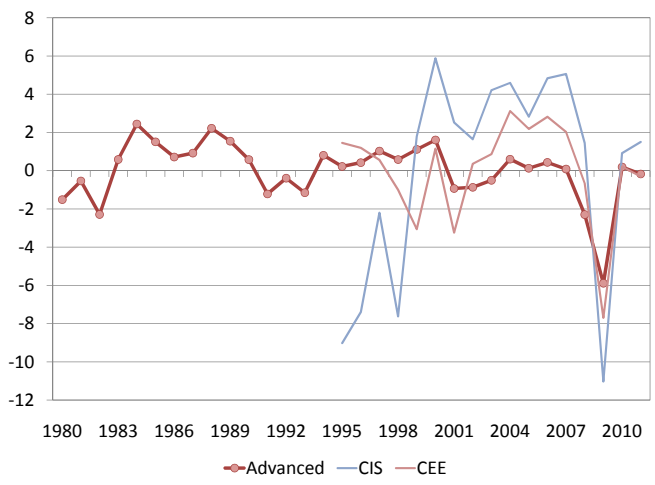

Source: World Economic Outlook, October 2010. Author's Calculations. Each panel reports the growth rate of output of the corresponding regions in deviation from the region's average growth rate.

Figure 1: Detrended Real Output Growth, by regions (percent p.a.) 
(a) Output Gap (log deviation from trend in percent p.a.)

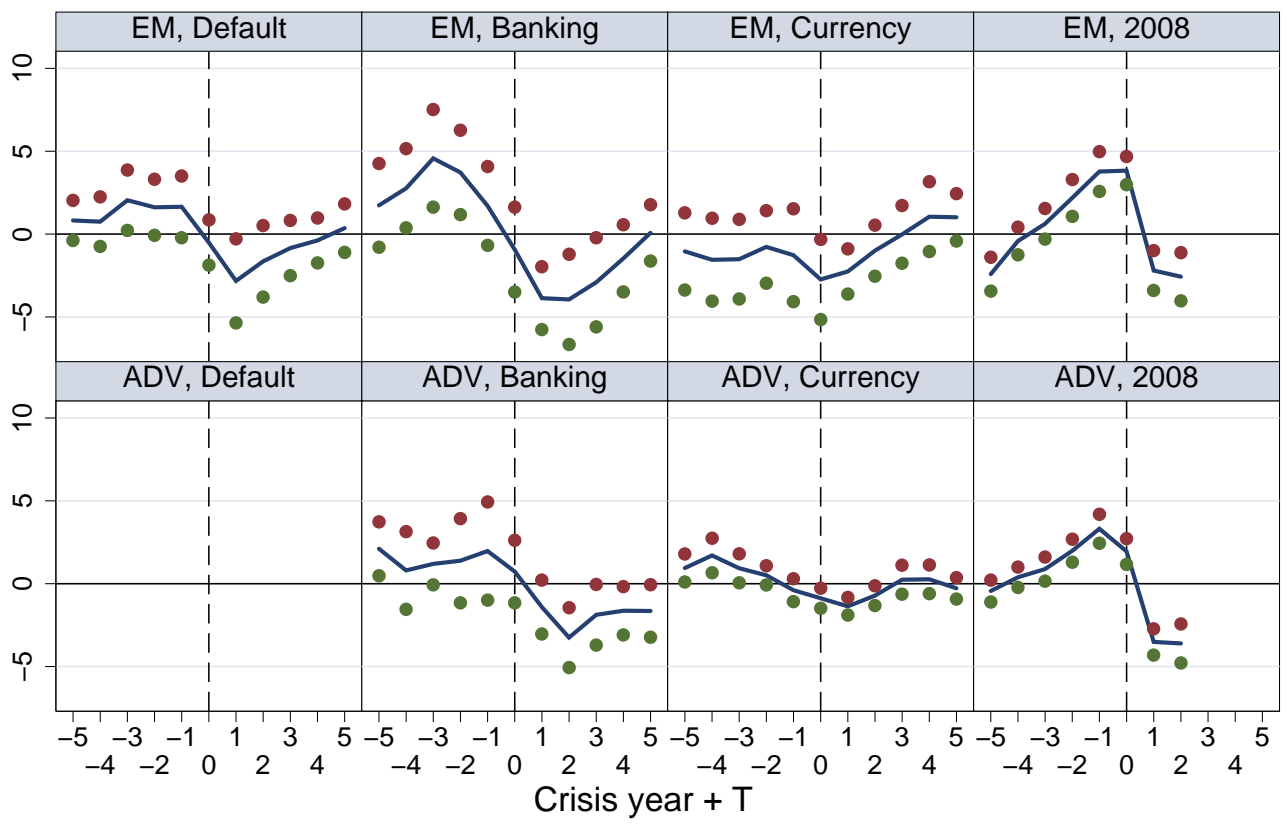

Graphs by Region and Crisis Type

(b) Inflation Rate (percent p.a.)

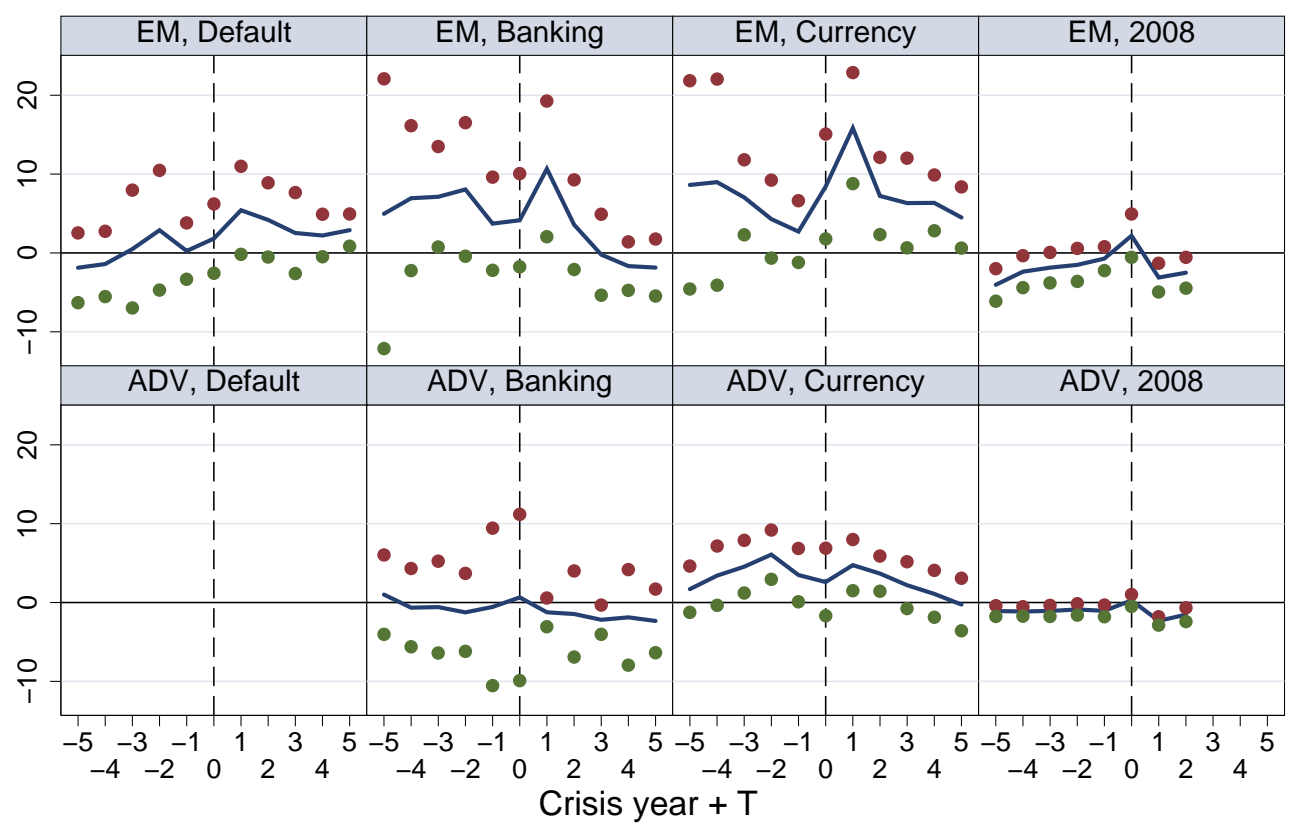

Graphs by Region and Crisis Type

Source: Author's Calculations. Estimation of equation 1 on annual data, between 1973 and 2010. The estimates of conditional means of each variable, relative to 'tranquil times' are reported on the vertical axis. The horizontal axes represents the number of years before (negative sign) and after a crisis of a given type (in the different columns). Estimates in the top row are for emerging market economies; in the bottom row for advanced economies. The dots denote a $95 \%$ confidence interval for each conditional mean. For inflation, a median regression is estimated.

Figure 2: Empirical Regularities during Past and Present Crisis (1): Output Gap and Inflation 
(a) Gross Public Debt percent of GDP)

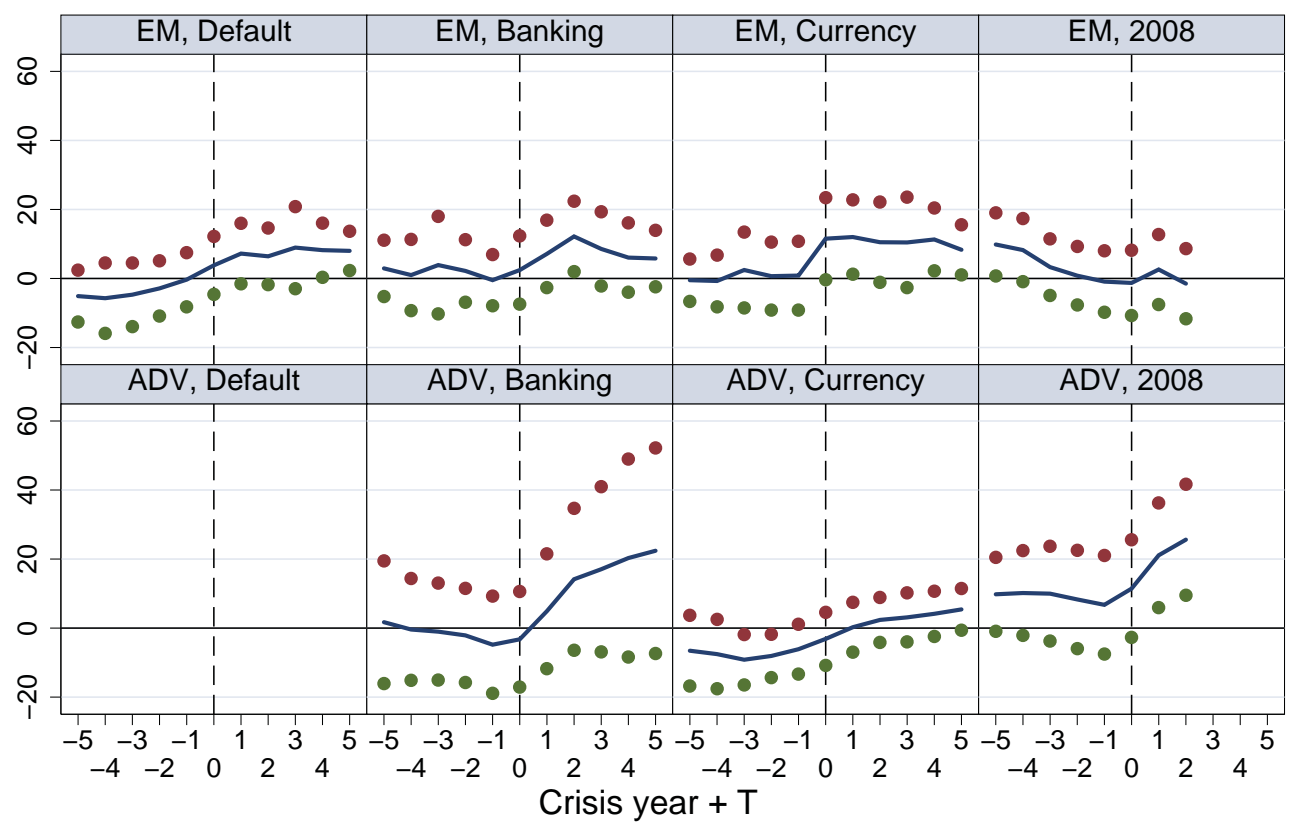

Graphs by Region and Crisis Type

(b) Real Interest Rate (percent p.a.)

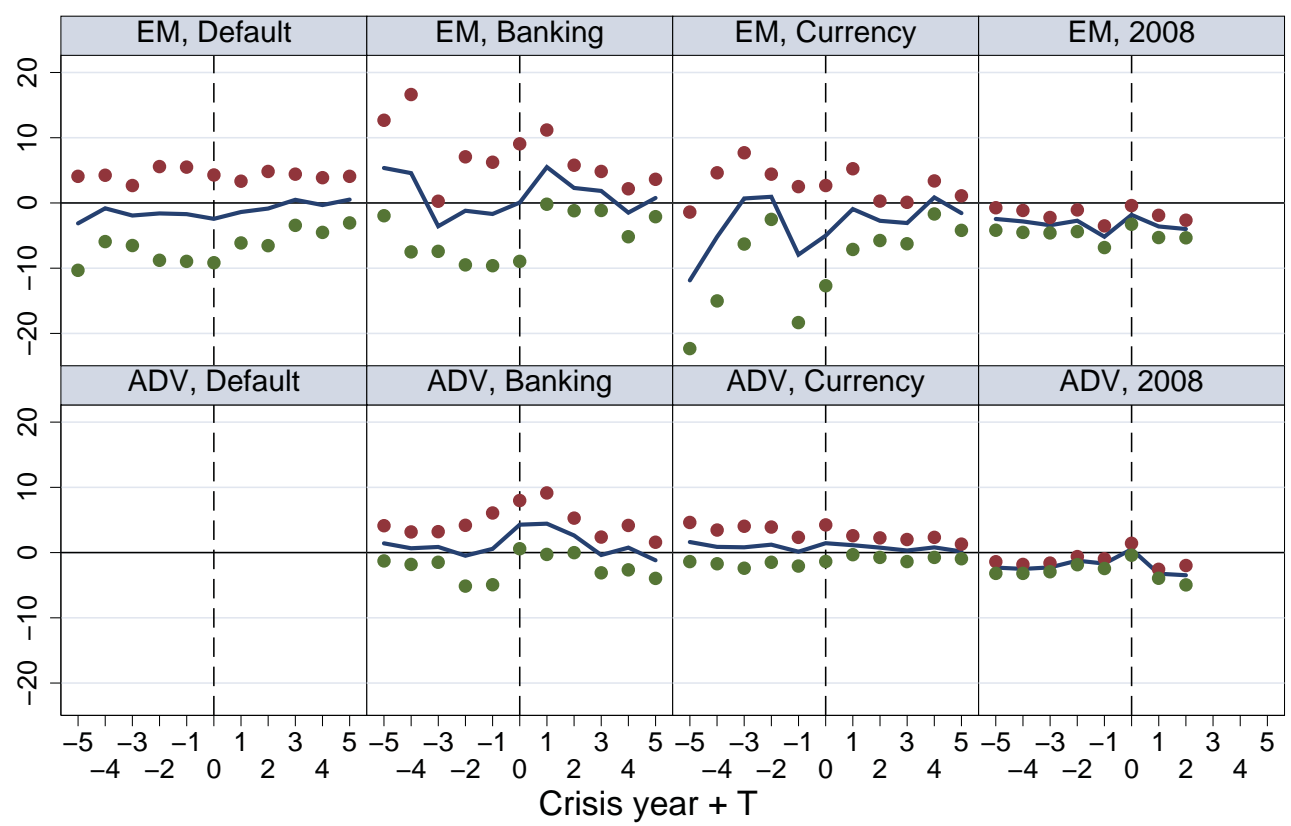

Graphs by Region and Crisis Type

Source: Author's Calculations. Estimation of equation (1) on annual data, between 1973 and 2010. The estimates of conditional means of each variable, relative to 'tranquil times' are reported on the vertical axis. The horizontal axes represents the number of years before (negative sign) and after a crisis of a given type (in the different columns). Estimates in the top row are for emerging market economies; in the bottom row for advanced economies. The dots denote a $95 \%$ confidence interval for each conditional mean. For the real interest rate, a median regression is estimated.

Figure 3: Empirical Regularities during Past and Present Crisis (2): Public Debt and Real Interest Rates 
(a) Domestic Credit (percent of GDP)

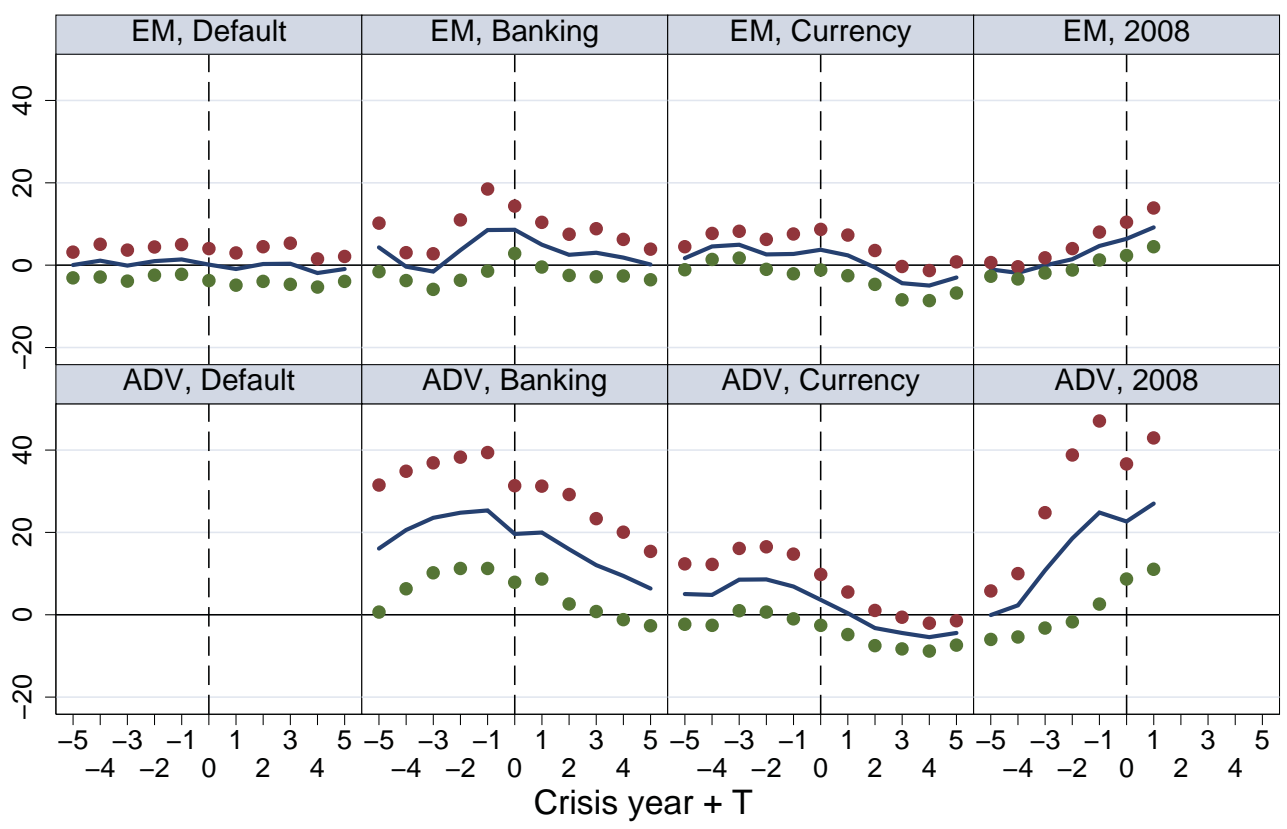

Graphs by Region and Crisis Type

\section{(b) External Leverage}

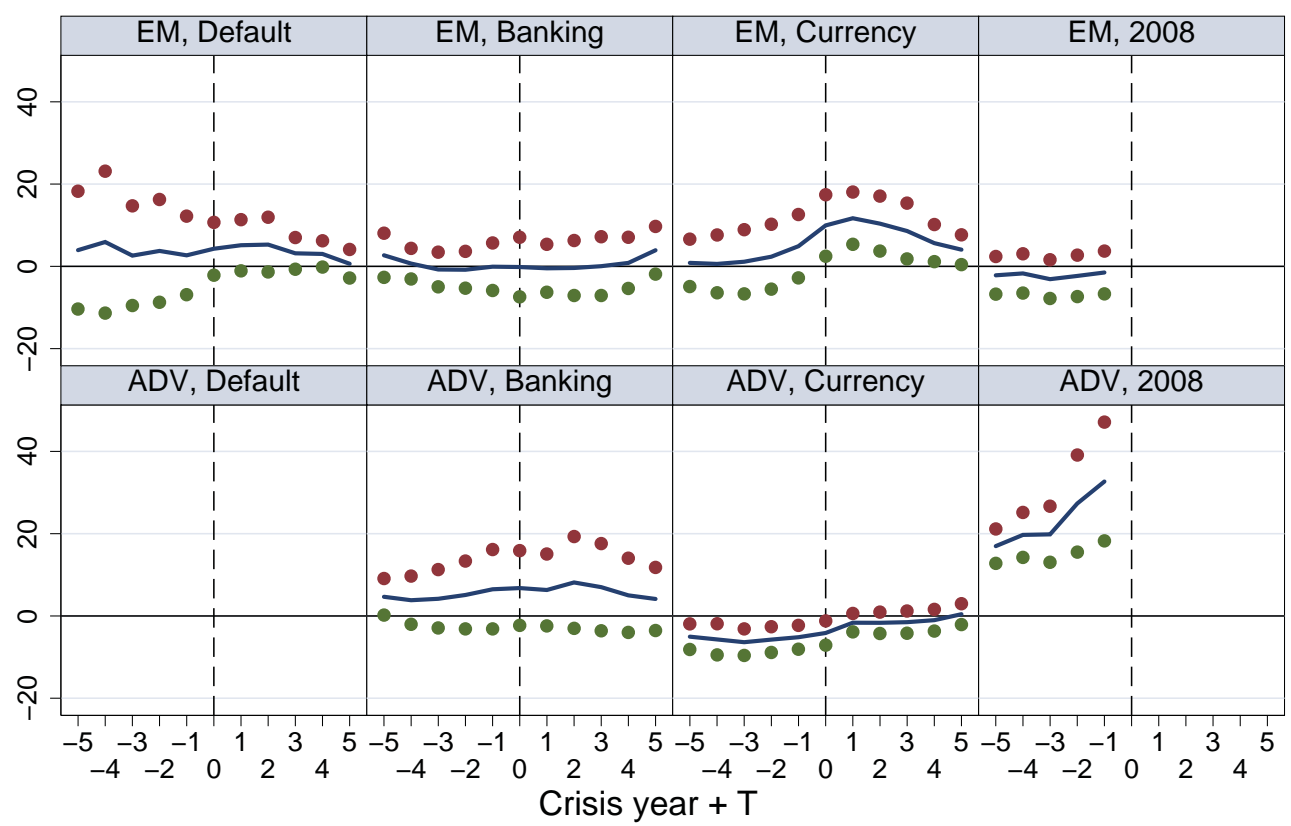

Graphs by Region and Crisis Type

Source: Author's Calculations. Estimation of equation (1) on annual data, between 1973 and 2010. The estimates of conditional means of each variable, relative to 'tranquil times' are reported on the vertical axis. The horizontal axes represents the number of years before (negative sign) and after a crisis of a given type (in the different columns). Estimates in the top row are for emerging market economies; in the bottom row for advanced economies. The dots denote a $95 \%$ confidence interval for each conditional mean.

Figure 4: Empirical Regularities during Past and Present Crisis (3): Internal and External Leverage 
(a) Current Account (percent of GDP)

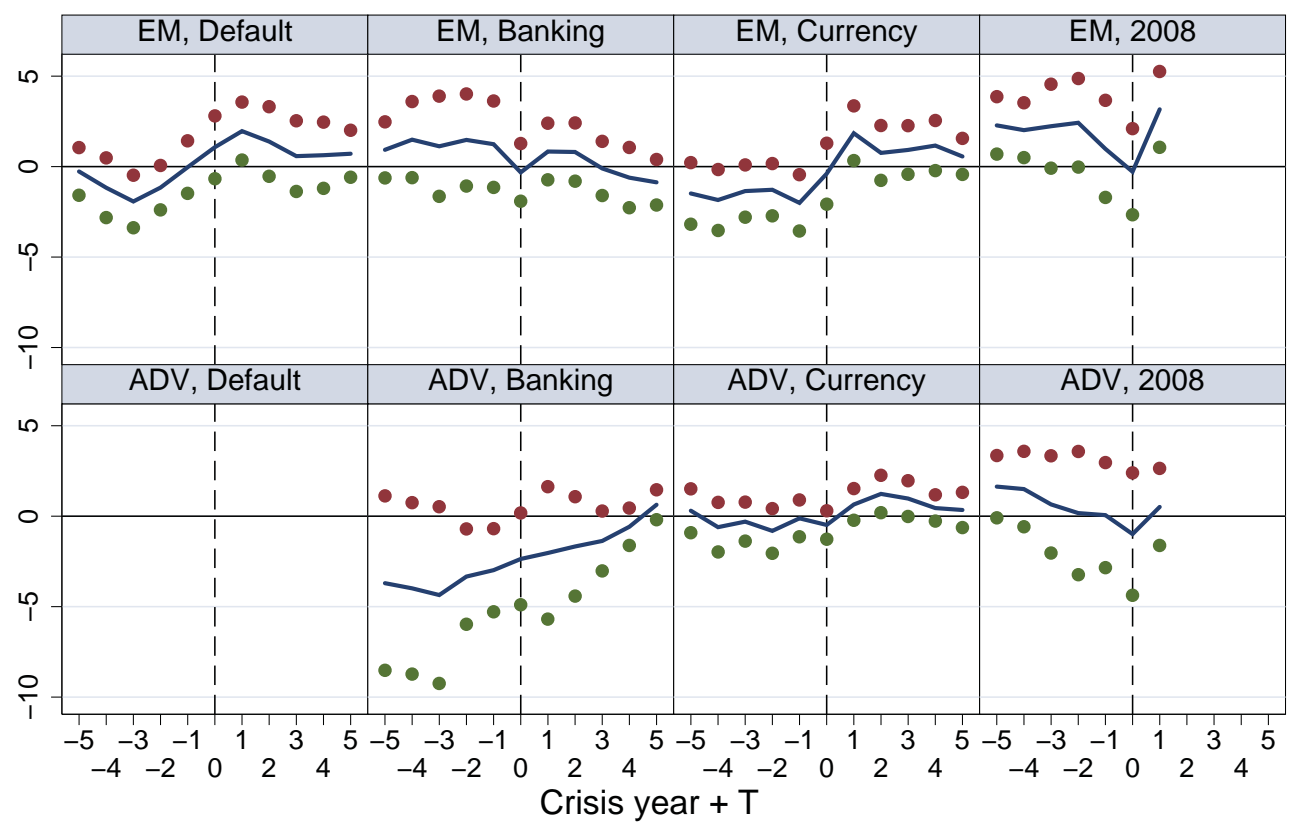

Graphs by Region and Crisis Type

(b) Real Exchange Rate (log deviation from trend in percent)

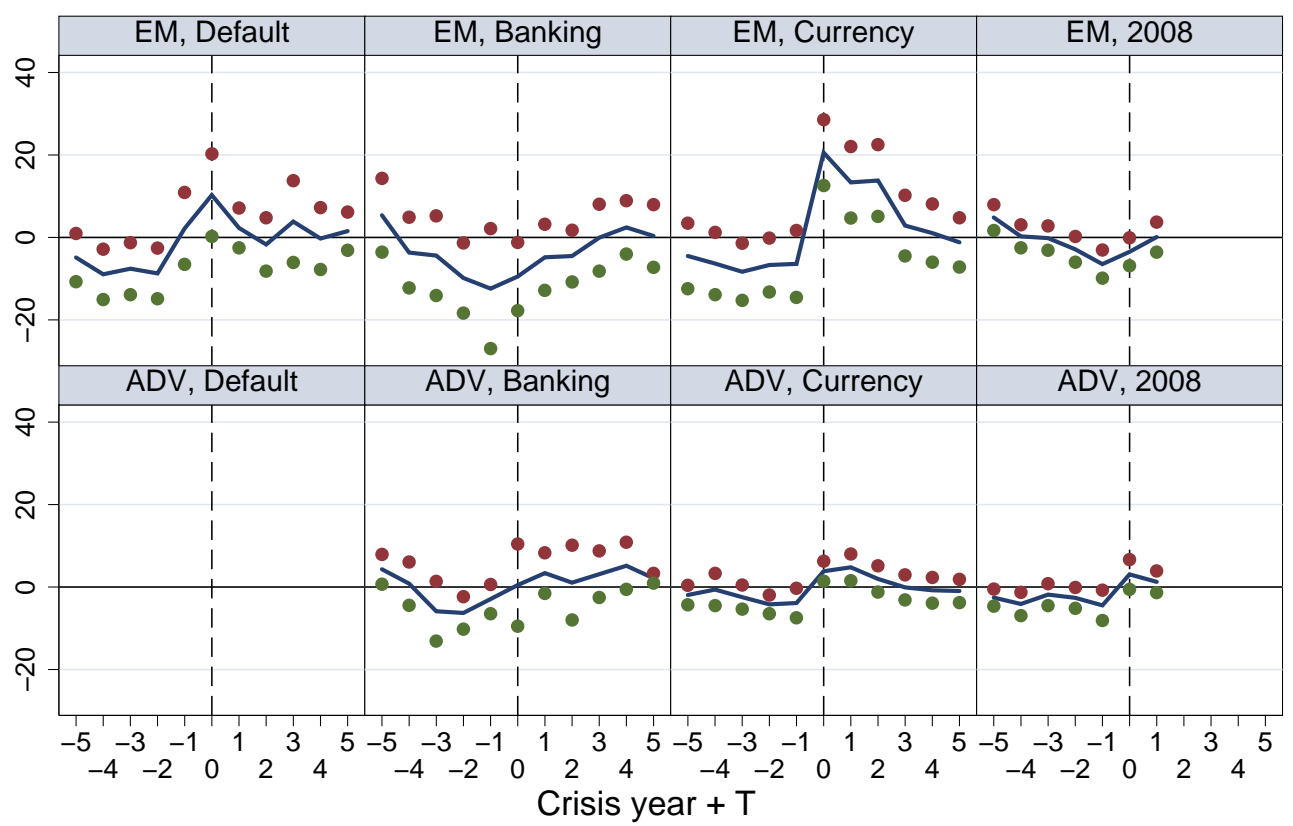

Graphs by Region and Crisis Type

Source: Author's Calculations. Estimation of equation (1) on annual data, between 1973 and 2010. The estimates of conditional means of each variable, relative to 'tranquil times' are reported on the vertical axis. The horizontal axes represents the number of years before (negative sign) and after a crisis of a given type (in the different columns). Estimates in the top row are for emerging market economies; in the bottom row for advanced economies. The dots denote a $95 \%$ confidence interval for each conditional mean.

Figure 5: Empirical Regularities during Past and Present Crisis (4): Current Account and Real Exchange Rate 
(a) Foreign Reserves (percent of GDP)

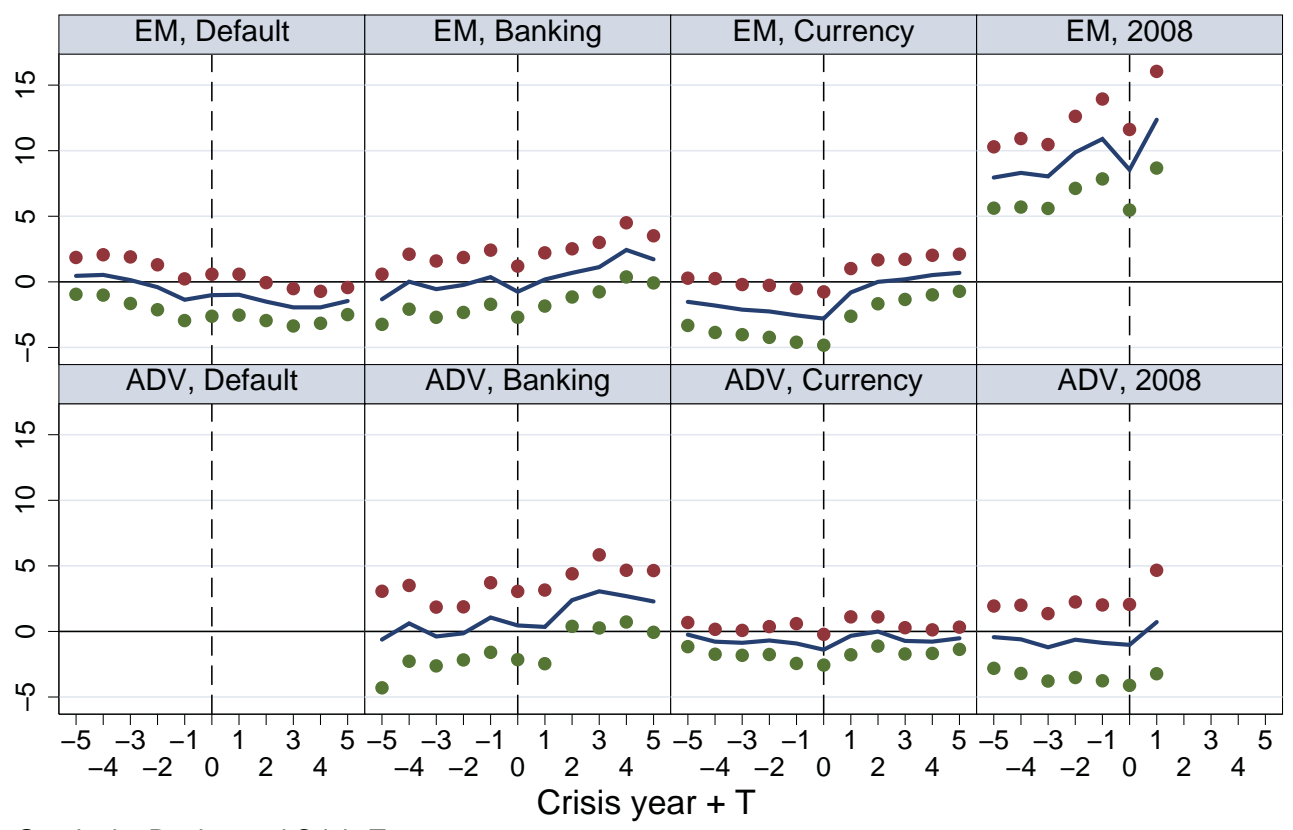

Graphs by Region and Crisis Type

(b) Short-Term External Debt (percent of GDP)

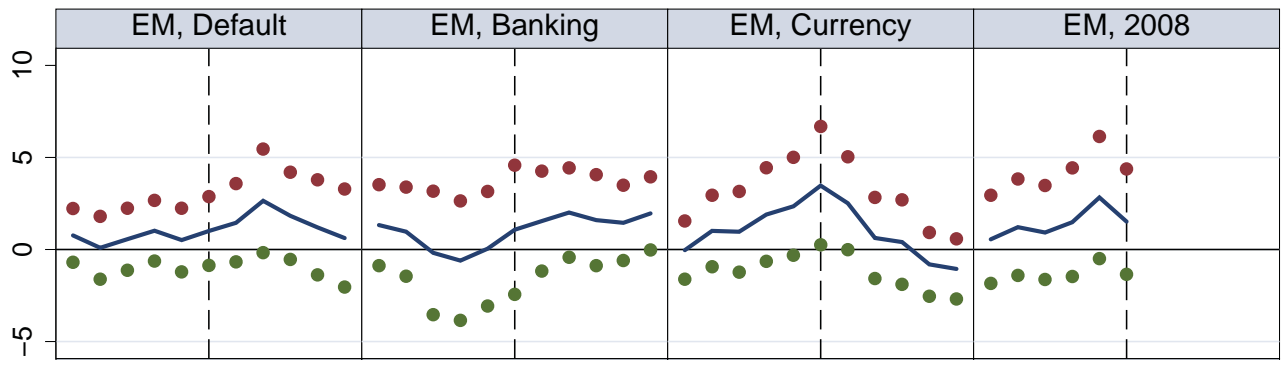

Source: Author's Calculations. Estimation of equation (1) on annual data, between 1973 and 2010. The estimates of conditional means of each variable, relative to 'tranquil times' are reported on the vertical axis. The horizontal axes represents the number of years before (negative sign) and after a crisis of a given type (in the different columns). Estimates in the top row are for emerging market economies; in the bottom row for advanced economies. The dots denote a $95 \%$ confidence interval for each conditional mean. Short-term external debt only available for EMEs.

Figure 6: Empirical Regularities during Past and Present Crisis (5): Foreign Reserves and Short Term External Debt 
(a) Output Gap

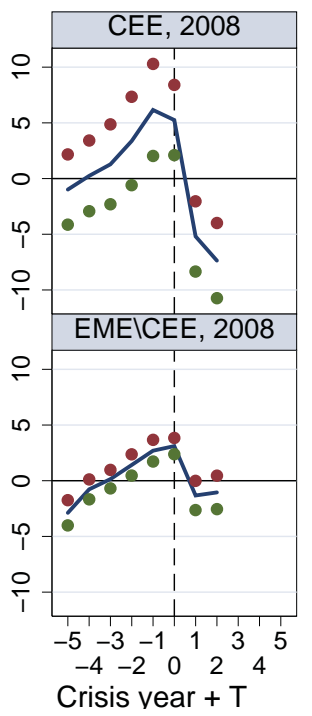

(d) Current Account

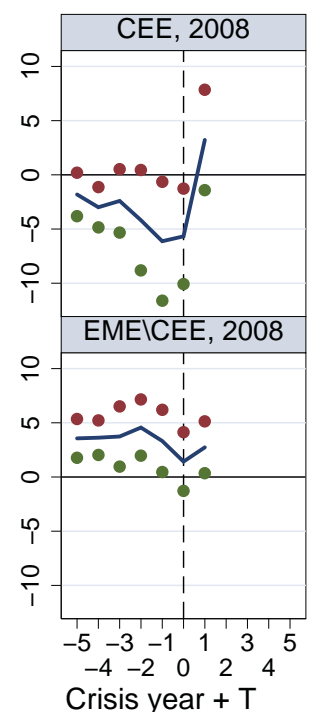

(b) Domestic Credit

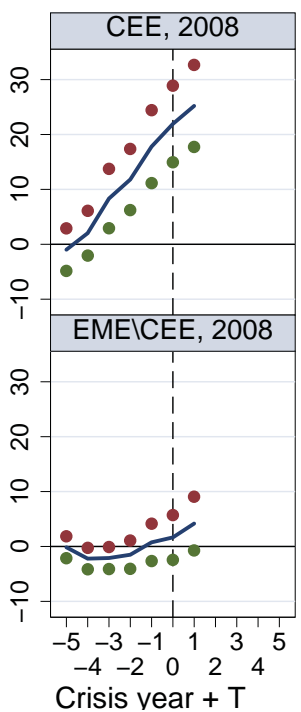

(e) Short-Term Debt

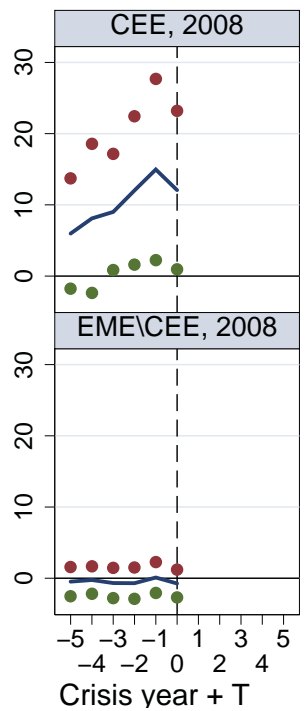

(c) External Leverage

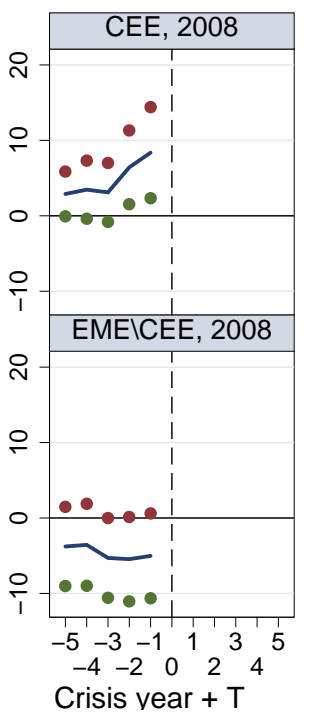

(f) Real Exchange Rate

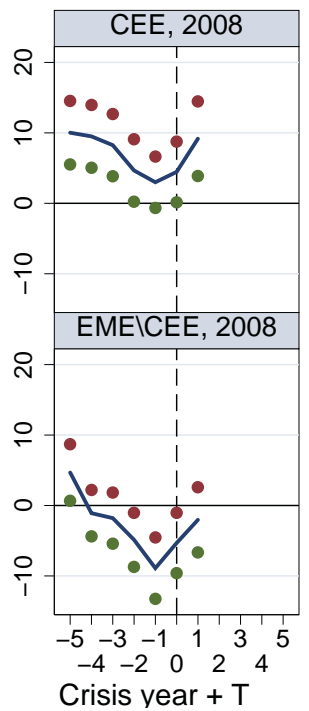

Source: Author's Calculations. Estimation of equation (1) on annual data, between 1973 and 2010. The estimates of conditional means of each variable, relative to 'tranquil times' are reported on the vertical axis. The horizontal axes represents the number of years before (negative sign) and after a crisis of a given type (in the different columns). Estimates in the top row are for central and eastern european economies; in the bottom row for other emerging economies. The dots denote a $95 \%$ confidence interval for each conditional mean. Output gap and Real exchange rate in percentage deviation from trend. Domestic credit, current account surplus, short-term external debt in percent of output. See appendix A for a description of external leverage.

Figure 7: Empirical Regularities during the 2008 Crisis: CEE vs other Emerging Market Economies 